\title{
14. MAJOR ELEMENT AND Sr ISOTOPE COMPOSITION OF INTERSTITIAL WATERS IN SEDIMENTS FROM LEG 129: THE ROLE OF DIAGENETIC REACTIONS ${ }^{1}$
}

\author{
Christian France-Lanord, ${ }^{2}$ Annie Michard, ${ }^{2,3}$ and Anne Marie Karpoff ${ }^{4}$
}

\begin{abstract}
Interstitial water samples from Leg 129, Sites 800, 801, and 802 in the Pigafetta and Mariana basins (central western Pacific), have been analyzed for major elements, B, Li, Mn, Sr, and ${ }^{87} \mathrm{Sr} /{ }^{86} \mathrm{Sr}$. At all sites waters show enrichment in $\mathrm{Ca}$ and $\mathrm{Sr}$ and are depleted in $\mathrm{Mg}, \mathrm{K}, \mathrm{Na}, \mathrm{SO}_{4}, \mathrm{~B}$, alkalinity, and ${ }^{87} \mathrm{Sr}$ compared to seawater. These changes are related to alteration of basaltic material into secondary smectite and zeolite and recrystallization of biogenic carbonate. Water concentration depth profiles are characterized by breaks due to the presence of barriers to diffusion such as chert layers at Sites 800 and 801 and highly cemented volcanic ash at Site 802 .

In Site 800 , below a chert layer, concentration depth profiles are vertical and reflect slight alteration of volcanic matter, either in situ or in the upper basaltic crust. Release of interlayer water from clay minerals is likely to induce observed $\mathrm{Cl}$ depletions.

At Site 801, two units act as diffusion barrier and isolate the volcaniclastic sediments from ocean and basement. Diagenetic alteration of volcanic matter generates a chemical signature similar to that at Site 800 . Just above the basaltic crust, interstitial waters are less evolved and reflect low alteration of the crust, probably because of the presence in the sediments of layers with low diffusivities.

At Site 802 , in Miocene tuffs, the chemical evolution generated by diagenetic alteration is extreme $\left(\mathrm{Ca}=130 \mathrm{mmol},{ }^{87} \mathrm{Sr} /{ }^{86} \mathrm{Sr}\right.$ $=0.7042$ at 83 meters below seafloor $)$ and is accompanied by an increase of the $\mathrm{Cl}$ content $(630 \mathrm{mmol})$ due to water uptake in secondary hydrous phases. Factors that enhance this evolution are a high sediment accumulation rate, high cementation preventing diffusive exchange and the reactive composition of the sediment (basaltic glass). The chemical variation is estimated to result in the alteration of more than $20 \%$ of the volcanic matter in a nearly closed system.
\end{abstract}

\section{INTRODUCTION}

The chemical and isotopic variations of interstitial waters extracted from deep-sea sediments from many Deep Sea Drilling Project-Ocean Drilling Program (DSDP-ODP) sites are the result of diffusive exchange between seawater and the basaltic upper crust undergoing alteration (e.g., McDuff and Gieskes, 1976). The classical pattern observed is a mole-to-mole increase of $\mathrm{Ca}$ and depletion of $\mathrm{Mg}$. Diagenetic reactions also generate chemical variations in the interstitial waters. Volcanic ash in the sediment is commonly altered and produces a chemical pattern similar to that of alteration of basaltic upper crust (e.g., Kastner and Gieskes, 1976). The chemical depth profiles at a given site represent, therefore, the synthesis of three main processes: diffusion, diagenesis, and alteration of the basaltic crust. All are controlled by a set of more or less independent factors in the sediment: mineralogical composition, diffusive properties, chemical reactivities, sedimentation rate, porosity, permeability, and temperature.

In this paper we present the chemical and $\mathrm{Sr}$ isotope composition of interstitial waters sampled during Leg 129. The chemical transformations of the interstitial waters are interpreted on the basis of mineralogical, chemical, isotopic, and physical data from the sediments. Three sites $(800,801$, and 802$)$ were drilled in the Pigafetta and East Mariana basins in order to recover Jurassic sediment and oceanic crust (Fig. 1). Site 801 reached Callovian-Bathonian sediments overlying alkali and tholeiitic basalts, which are a remnant of the Jurassic superocean that once covered two-thirds of the Earth's surface. At all three sites there are thick Cretaceous volcaniclastic

\footnotetext{
'Larson, R. L., Lancelot, Y., et al., 1992. Proc. ODP. Sci. Results, 129: College Station, TX (Ocean Drilling Program).

${ }^{2}$ Centre de Recherches Pétrographiques et Géochimiques-CNRS, BP 20, 54501 Vandoeuvre Cedex, France.

${ }^{3}$ Laboratoire Géosciences de l'environnement, Université St. Jérôme, C.O. 431 , 13397 Marseille Cedex 13, France.

${ }^{4}$ Centre de géochimie de la surface — CNRS, 1 rue de Blessig, 67000 Strasbourg, France.
}

sequences which are overlain at Sites 800 and 801 by siliceous layers. At these sites the influence of diffusion is considerably reduced because of the presence of a high degree of cementation. These diffusion barriers allow us to examine closely the budgets of diagenetic reactions and the chemical behavior of smectite-rich sediments. At Site 802 concentrations of most elements reach extreme values similar to those observed at several recently drilled ODP sites in Miocene-Oligocene volcaniclastic sediments (Egeberg et al., 1990a, 1990b; Collot, Greene, Stokking, et al., 1992; Parson, Hawkins, Allan, et al., 1992; Blank, 1991).

\section{METHODS}

Water samples were extracted by squeezing 5 - to 10 -cm-long whole-round core sections at room temperature in a titanium and stainless steel piston modified after Manheim and Sayles (1974). Shipboard analyses include $\mathrm{pH}$, salinity, chlorinity, and alkalinity, and concentrations of calcium, magnesium, sulfate, potassium, strontium, silica, and manganese. Shipboard data and techniques are discussed in the Initial Reports (Lancelot, Larson, et al., 1990). Concentrations of $\mathrm{Na}, \mathrm{Mg}, \mathrm{K}$, and $\mathrm{Li}$ were measured by atomic absorption in absorption mode, and B, complexed with carminic acid, was measured by a colorimetric method.

${ }^{87} \mathrm{Sr} /{ }^{86} \mathrm{Sr}$ ratios and $\mathrm{Sr}$ content were measured on a six-collector 262 Finnegan-Mat mass spectrometer in static mode. Sr isotope analyses were done on interstitial water samples and rock samples. Rock samples were leached with $0.5 \mathrm{~N} \mathrm{HCl}$ acid and rinsed with distilled water. After centrifugation, the acid leachate and first rinse were combined and dried. Part of the dried material was weighed and spiked (leachate), as was a part of the residual material (residue). Hence, rock analyses comprise analyses of (1) the leached residue (mostly silicates) and (2) the leachate where $\mathrm{Sr}$ is mainly released by carbonates but also by hydroxides and interstitial water salts. Chemical separation followed the technique described by Alibert et al. (1983).

On the basis of chemical composition of the drilling mud and seawater and of the period of injection of the mud during drilling, no 


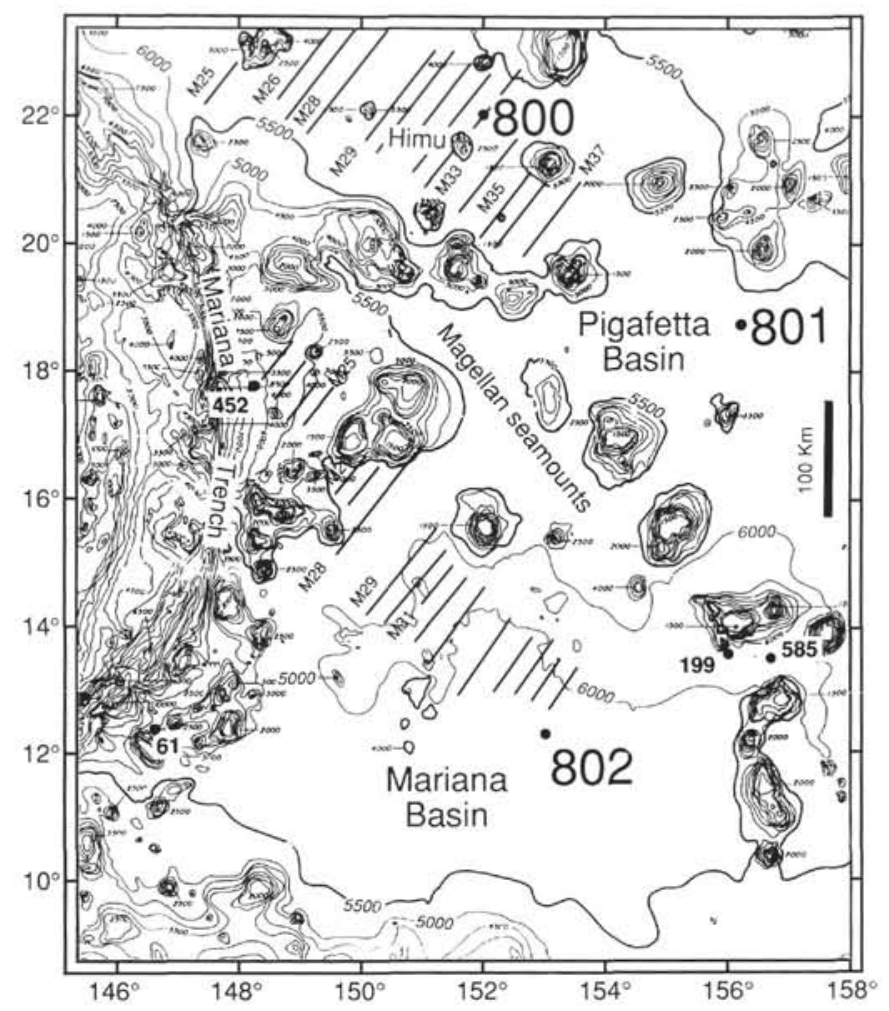

Figure 1. Location of Sites 800,801 , and 802 and DSDP sites in the area of the Pigafetta and East Mariana basins (Lancelot, Larson, et al., 1990). Bathymetry in meters. Diagonal lines denote magnetic anomalies.

contamination by seawater and/or drilling fluids is evident (Lancelot, Larson, et al., 1990). None of the observed chemical variations can be explained by the mixing of pore water with seawater or drilling fluids. Moreover, isotopic compositions of Sr and hydrogen (France-Lanord and Sheppard, this volume) show no evidence of seawater addition.

Major and trace elements analyses of solid sediment were done by ICP at CNRS-CRPG, Nancy, France (K. Govindaraju, analyst) after melting with $\mathrm{Ce}$ metaborate. Analyses were done on squeezed cake samples which reduce the contribution of interstitial water salts. This is especially important for $\mathrm{Na}$ concentrations.

\section{SITE DESCRIPTIONS AND RESULTS}

Analyses of interstitial water are given in Table 1 and shown as concentration vs. depth diagrams in Figures 2, 3, 4, and 5. Corresponding sediment lithologic descriptions and whole-rock X-ray diffraction (XRD) determinations are reported in Table 2, and major and trace element analyses of solid sediments in Tables 3 and 4, respectively.

\section{Site 800-Pigafetta Basin}

Site 800 is located at a water depth of $5686 \mathrm{~m}$ in the northern Pigafetta Basin near the Himu Seamount (Fig. 1). The sediments range in age from Cenozoic to Berriasian. They have been divided into five units (Fig. 2):

Unit I ( $0-38 \mathrm{~m}$ below seafloor [mbsf]): Tertiary to upper Campanian zeolitic pelagic brown clay.

Unit II (38-78 mbsf): upper Campanian to Turonian brown chert and porcellanite.

Unit III (78-229 mbsf): Cenomanian to lower Albian gray chert and silicified limestones and nannofossil chalk at the base. Porosities are low ( 7 to $20 \mathrm{vol} \%$ ) at the top.
Unit IV (229-450 mbsf): Aptian volcaniclastic turbidites in sequences of interbedded clay, claystones, silty clay, silty sandstone, and sandstones. They are composed of (1) redeposited volcanic ash, with sporadic biogenic carbonates in the upper part and (2) secondary smectites, zeolites, and calcite. Volcanic material is possibly derived from the nearby Himu Seamount (Fig. 1) whose age is $\approx 120$ Ma (Smith et al., 1989).

Unit V (450-498 mbsf): Hauterivian to Berriasian claystone and radiolarite.

The sediment sequence overlies massive dolerite sills.

Eight samples were squeezed, one from Unit I and seven from Unit IV and below (Table 1). Because of both the lithology and scarce recovery, no samples were taken in Units II and III. The major solute concentrations differ above and below the chert layers (Fig. 2). Concentrations at $22 \mathrm{mbsf}$ are similar to seawater values. Below, in Unit $\mathrm{IV}, \mathrm{Na}, \mathrm{Mg}, \mathrm{K}, \mathrm{SO}_{4}$, and alkalinity concentrations are strongly reduced. $\mathrm{Cl}$ is also depleted to about $95 \%$ of its value in seawater. The extent of the depletion is lower at 327 and $473 \mathrm{mbsf}$. The overall trend of Ca concentration is the opposite of the other major constituents.

The $\mathrm{Sr}$ concentration is 3.5 times higher than in seawater at 232 mbsf and remains at similar concentrations below. ${ }^{87} \mathrm{Sr} /{ }^{86} \mathrm{Sr}$ ratios are relatively constant in Units IV and V, between 0.70635 and 0.70661 . These values are significantly lower than those of $115-$ to $135-\mathrm{Ma}$ seawater (0.7072-0.7075; Koepnick et al., 1985).

\section{Site 801-Pigafetta Basin}

Site 801 is situated within the "Jurassic magnetic quiet zone" in the central part of the Pigafetta Basin to the southeast of Site 800 (Fig. 1), at a water depth of $5674 \mathrm{~m}$. The $462 \mathrm{~m}$ of sediments that were cored range in age from Cenozoic to Callovian and were divided into five units (Fig. 3):

Unit I (0-64 mbsf): Tertiary to Campanian pelagic brown clay.

Unit II (64-126 mbsf): Campanian to Turonian brown chert and porcellanite.

Unit III (126-318 mbsf): Cenomanian and Albian volcaniclastic turbidites with sporadic interlayers of pelagic clay, radiolarite, chert, and chalk. Turbidites are composed of volcanic ash and fragments (glass, feldspar, pyroxene, etc.) and secondary smectite, zeolite, and calcite.

Unit IV ( 318-443 mbsf): Valanginian to Oxfordian brown radiolarite with dark brown chert. Chert is abundant at the top and porosity is very low.

Unit V (443-462 mbsf): Callovian-Bathonian umber radiolarite and claystone. Metalliferous sediments consisting of pelagic clay, radiolarite, and hydrothermal hydroxide.

The basement consists of an upper alkali olivine basalt sequence (462-591 mbsf) and a lower tholeiitic pillow basalt sequence (462-591 mbsf). They are separated by a silicified hydrothermal deposit of hematite.

Seven interstitial water samples were squeezed, two from above chert Unit II and four below (Table 1). No samples were taken in the chert layer (Unit II). Interstitial water composition (Fig. 3) are chemically similar to modern seawater in the brown clay of Unit I. Only Si and $\mathrm{SO}_{4}$ are significantly higher at 36 mbsf. Below Unit II, interstitial water extracted from the volcaniclastic turbidites display a general depletion in $\mathrm{Mg}, \mathrm{K}$, and $\mathrm{Na}$ and an enrichment in $\mathrm{Ca}$. The overall depletion in cations is balanced by alkalinity, and $\mathrm{SO}_{4}$ decreases while $\mathrm{Cl}$ remains constant. In Unit $\mathrm{V}$, these changes are less significant than in the volcaniclastic turbidites.

The B content is high at the top of the sequence ( $783 \mu \mathrm{mol}$ at $23 \mathrm{mbsf})$ compared to seawater. Below the chert the concentrations are variable between 300 and $500 \mu \mathrm{mol}$. Si is high $(427 \mu \mathrm{mol})$ at $175 \mathrm{mbsf}$, where opal is abundant, and remains constant below at $\approx 200 \mu \mathrm{mol}$. Sr is almost constant at $260 \pm 20 \mu \mathrm{mol}$ below Unit II. The ${ }^{87} \mathrm{Sr}{ }^{86} \mathrm{Sr}$ ratios are significantly lower than contemporaneous seawater in Unit III. In Unit V, the ${ }^{87} \mathrm{Sr} /{ }^{86} \mathrm{Sr}$ ratio of pore water at $454 \mathrm{mbsf}$ is in the range of 160 -Ma Jurassic seawater (0.7068-0.7073; Koepnick et al., 1990). 
Table 1. Interstitial water concentration data and $\mathrm{Sr}$ isotope compositions.

\begin{tabular}{|c|c|c|c|c|c|c|c|c|c|c|c|c|c|c|c|c|}
\hline $\begin{array}{l}\text { Core, section, } \\
\text { interval }(\mathrm{cm})\end{array}$ & $\begin{array}{l}\text { Deptha } \\
\text { (mbsf) }\end{array}$ & $\mathrm{pH}$ & $\underset{(\mathrm{mmol})}{\mathrm{Cl}}$ & $\underset{(\mathrm{mmol})}{\mathrm{SO}_{4}}$ & $\begin{array}{l}\text { Alkalinity } \\
\text { (meq) }\end{array}$ & $\underset{(\mathrm{mmol})}{\mathrm{Na}^{\mathrm{b}}}$ & $\underset{(\mathrm{mmol})}{\mathrm{Na}}$ & $\underset{(\mathrm{mmol})}{\mathrm{Ca}}$ & $\underset{(\mathrm{mmol})}{\mathrm{K}}$ & $\underset{(\mathrm{mmol})}{\mathrm{Mg}}$ & $\begin{array}{c}\text { B } \\
(\mu \mathrm{mol})\end{array}$ & $\begin{array}{c}\mathrm{Si} \\
(\mu \mathrm{mol})\end{array}$ & $\underset{(\mu \mathrm{mol})}{\mathrm{Sr}}$ & $\begin{array}{c}\mathrm{nM} \\
(\mu \mathrm{mol})\end{array}$ & $\underset{(\mu \mathrm{mol})}{\mathrm{Li}}$ & ${ }^{87} \mathrm{Sr} /{ }^{67} \mathrm{Sr}$ \\
\hline \multicolumn{17}{|l|}{ 129-800A- } \\
\hline $4 R-2,25-30$ & 22 & 7.5 & 569 & 25.8 & 2.28 & 480 & 477 & 10.5 & 11.8 & 53.1 & 759 & 377 & '89 & 2 & 33 & \\
\hline $26 \mathrm{R}-2.140-148$ & 232 & 8.2 & 537 & 17.6 & 0.53 & 436 & & 56.0 & 2.8 & 10.6 & & & ${ }^{c} 321$ & 87 & & \\
\hline $27 \mathrm{R}-1,140-150$ & 239 & 8.1 & 527 & 14.5 & 0.51 & 416 & 413 & 58.3 & 1.8 & 8.9 & 509 & 546 & 299 & 58 & & $0.706351 \pm 37$ \\
\hline $33 R-6,60-70$ & 296 & 7.8 & 530 & 14.0 & 0.58 & 416 & 417 & 58.2 & 1.4 & 11.0 & 591 & 206 & 318 & 33 & & $0.706584 \pm 24$ \\
\hline $37 R-2,0-10$ & 327 & 8.1 & 554 & 16.4 & 1.19 & 444 & 442 & 54.7 & 1.9 & 16.0 & & 193 & 297 & 49 & & $0.706607 \pm 30$ \\
\hline 4 IR-2, $0-10$ & 364 & 7.1 & 531 & 11.1 & 0.61 & 414 & 395 & 57.3 & 1.6 & 10.4 & 481 & 185 & 317 & 38 & & $0.706618 \pm 32$ \\
\hline $49 \mathrm{R}-2.140-150$ & 434 & 7.1 & 531 & 12.3 & 0.71 & 411 & 401 & 59.2 & 1.3 & 12.2 & 205 & 158 & 331 & 18 & 29 & $0.706584 \pm 24$ \\
\hline $54 \mathrm{R}-2,0-12$ & 473 & 8.2 & 554 & 13.2 & 0.64 & 426 & 404 & 60.8 & 2.0 & 14.4 & 346 & 231 & 337 & 6 & 30 & $0.706568 \pm 23$ \\
\hline \multicolumn{17}{|l|}{ 129.80IA- } \\
\hline $3 R-2,145-150$ & 23 & 7.5 & 562 & 29.3 & 2.83 & 483 & 473 & 10.9 & 11.2 & 52.0 & 783 & 200 & 84 & 0 & 30 & \\
\hline $5 R-2.145-150$ & 44 & 7.6 & 564 & 37.2 & 2.92 & 496 & 462 & 12.0 & 11.6 & 53.2 & 715 & 323 & '86 & 4 & 27 & \\
\hline $19 R-2,65-73$ & 175 & 8.0 & 560 & 19.3 & 0.72 & 449 & 452 & 53.2 & 3.8 & 18.4 & 316 & 427 & 253 & 51 & 17 & $0.706455 \pm 22$ \\
\hline \multicolumn{17}{|l|}{$129.801 \mathrm{~B}-$} \\
\hline $5 R-2,0-10$ & 233 & 7.7 & 569 & 16.1 & 0.46 & 453 & 460 & 56.1 & 2.7 & 15.1 & 508 & 249 & 281 & 97 & 13 & $0.706383 \pm 24$ \\
\hline $8 \mathrm{R}-3.115-125$ & 265 & 8.1 & 543 & 16.8 & 0.64 & 441 & 436 & 46.6 & 2.4 & 18.6 & 315 & 233 & 238 & 123 & 13 & $0.706634 \pm 11$ \\
\hline $33 \mathrm{R}-1,143-150$ & 444 & 7.5 & 586 & 17.5 & 1.37 & 465 & 445 & 40.9 & 1.9 & 35.3 & 485 & 212 & 276 & 28 & & $0.707013 \pm 19$ \\
\hline $35 R-2,0-10$ & 454 & 7.9 & 572 & 21.0 & 1.28 & 458 & 452 & 40.4 & 2.0 & 36.0 & 324 & 218 & $c^{2} 280$ & 25 & 26 & \\
\hline \multicolumn{17}{|l|}{$129-802 \mathrm{~A}-$} \\
\hline $4 \mathrm{R}-1,140-150$ & 26 & 7.8 & 554 & 26.8 & 1.36 & 484 & 477 & 16.2 & 12.2 & 38.6 & 736 & 162 & 91 & 6 & 22 & $0.708022 \pm 39$ \\
\hline $6 \mathrm{R}-2,0-10$ & 44 & 8.3 & 547 & 36.5 & 0.75 & 492 & 489 & 42.3 & 11.0 & 15.4 & 433 & 78 & 135 & 13 & 6 & $0.706055 \pm 28$ \\
\hline $10 \mathrm{R}-2,140-150$ & 83 & 9.0 & 631 & 0.4 & 0.57 & 377 & 354 & 125.2 & 2.7 & 0.5 & 43 & 194 & 352 & 19 & 6 & $0.704271 \pm 18$ \\
\hline $13 R-1,53-58$ & 109 & 7.8 & 627 & 3.7 & 0.54 & 362 & 344 & 130.2 & 2.1 & 4.3 & 111 & 197 & 283 & 22 & 7 & $0.704330 \pm 30$ \\
\hline $19 \mathrm{R}-2,107-117$ & 162 & 8.5 & 610 & 9.9 & 0.60 & 402 & 388 & 108.3 & 2.1 & 3.9 & 308 & 157 & 468 & 16 & 6 & $0.705835 \pm 27$ \\
\hline $21 R-1,103-110$ & 179 & 8.4 & 613 & 11.9 & 0.58 & 398 & 381 & 114.3 & 1.7 & 3.6 & 315 & 124 & 459 & 11 & 6 & \\
\hline $26 \mathrm{R}-1,0-10$ & 225 & 8.1 & 612 & 12.2 & 0.44 & 390 & 388 & 118.4 & 1.8 & 2.9 & 324 & 151 & 487 & 20 & 11 & $0.706172 \pm 25$ \\
\hline $29 \mathrm{R}-3,29-34$ & 258 & 7.2 & 584 & 12.0 & 0.62 & 360 & 363 & 115.5 & 1.9 & 4.7 & 370 & 913 & 473 & 41 & 22 & \\
\hline $32 \mathrm{R}-2,140-150$ & 286 & 6.5 & 576 & 12.5 & 0.23 & 375 & & 96.1 & 4.6 & 12.9 & & 637 & 399 & 46 & & $0.706711 \pm 28$ \\
\hline $36 \mathrm{R}-1,80-88$ & 322 & & 614 & & & 423 & 423 & 81.8 & 3.9 & 11.8 & & & 350 & & & $0.707096 \pm 27$ \\
\hline $40 \mathrm{R}-2,140-150$ & 361 & 8.0 & 598 & 15.0 & 0.58 & 430 & 413 & 80.5 & 2.6 & 10.4 & 386 & 499 & 294 & 34 & 26 & $0.707002 \pm 23$ \\
\hline $43 \mathrm{R}-1,140-150$ & 384 & 7.9 & 579 & 15.1 & 0.58 & 425 & 415 & 77.3 & 2.5 & 12.1 & 282 & 556 & 303 & 48 & 23 & $0.707088 \pm 20$ \\
\hline $47 \mathrm{R}-2,140-150$ & 422 & 7.9 & 530 & 13.2 & 0.62 & 396 & 394 & 66.8 & 2.2 & 11.6 & 270 & 203 & 260 & 53 & & $0.706916 \pm 20$ \\
\hline $50 \mathrm{R}-2,140-150$ & 450 & 7.9 & 553 & 13.6 & 0.80 & 406 & 409 & 74.0 & 2.2 & 10.7 & 668 & 179 & 284 & 54 & & $0.706988 \pm 23$ \\
\hline $53 \mathrm{R}-1,120-130$ & 471 & & 557 & & & 388 & 395 & 68.9 & 2.5 & 12.5 & 336 & 652 & 265 & 20 & 11 & $0.707095 \pm 19$ \\
\hline $56 \mathrm{R}-2,140-150$ & 500 & 8.2 & 586 & 15.7 & 0.80 & 446 & 443 & 81.5 & 1.2 & 2.9 & 318 & 216 & 241 & 22 & 10 & $0.706920 \pm 23$ \\
\hline
\end{tabular}

Notes: Most $\mathrm{pH}, \mathrm{Cl}, \mathrm{SO}_{4}$, alkalinity, $\mathrm{Ca}, \mathrm{Mg}, \mathrm{K}, \mathrm{Si}$, and $\mathrm{Mn}$ data are shipboard analyses (Lancelot, Larson. et al., 1990). Mean value of ${ }^{\mathrm{kit}} \mathrm{Sr}$ spiked NBS 987 is $0.710219 \pm 18$.

aDepths rounded to the nearest meter.

${ }^{b}$ Calculated by charge balance.

"Analyzed by atomic absorption rather than by isotope dilution.

\section{Site 802-East Mariana Basin}

Site 802 is in the center of the East Mariana Basin, more than 300 $\mathrm{km}$ from any known seamounts or island arc (Fig. 1). The water depth is $5674 \mathrm{~m}$. The sediment sequence is $500 \mathrm{~m}$ thick and consists of redeposited material. It has been divided into nine units (Fig. 4):

Unit I ( $0-15$ mbsf): Neogene brown clay.

Subunits IIA and IIB (15-254 mbsf): Miocene to Eocene tuff with indurated, well-preserved hyaloclastites and volcanic ash. Between 15 and 160 mbsf (Subunit IIA) the tuffs are well cemented. They are intercalated with a few layers of pelagic clay, and in the lower half they are mixed with chalk. Secondary minerals include smectites and zeolites and can range from $10 \%$ to $90 \%$ of the rock. Horizontal fractures of thaumasite $\left(\mathrm{Ca}_{3} \mathrm{Si}(\mathrm{OH})_{6} \mathrm{CO}_{3} \mathrm{SO}_{4}, 12 \mathrm{H}_{2} \mathrm{O}\right)$, pure or mixed with zeolite, are common at the top. The mineralogy is fully described in Karpoff et al. (this volume).

Unit III (254-330 mbsf): upper Paleocene nannofossil chalk, probably redeposited as a gravity flow.

Unit IV ( $330-348 \mathrm{mbsf}$ ): Maestrichtian zeolitic pelagic claystone.

Unit V (348-460 mbsf): Campanian volcaniclastic turbidites with claystone, porcellanite, and debris flow.

Units VI to IX (460-509 mbsf): Cenomanian to upper Albian brown claystone, radiolarian limestone, and volcaniclastic turbidites.

The basement consists of remarkably fresh extrusive basalt.

Interstitial water samples were squeezed from sediment cores at 16 depths between 26 and 500 mbsf (Table 1). The depth profiles show a clear break between 26 and 83 mbsf, with extremely large increases in $\mathrm{Ca}, \mathrm{Cl}, \mathrm{pH}$, and $\mathrm{Sr}$, and a strong decrease in ${ }^{87} \mathrm{Sr} /{ }^{86} \mathrm{Sr}$ ratios, $\mathrm{Mg}, \mathrm{K}, \mathrm{Na}, \mathrm{SO}_{4}$, alkalinity, $\mathrm{B}$, and $\mathrm{Li}$. Below, the compositions are generally constant (Figs. 4 and 5). From 258 to 500 mbsf, the trend is a progressive decrease of salinity (about 39\% to 34\%o) due to decreases in $\mathrm{Ca}$ and $\mathrm{Cl}$ contents. In this interval, $\mathrm{Na}$ and $\mathrm{Mg}$ contents increase slightly.

Pore-water ${ }^{87} \mathrm{Sr} /{ }^{86} \mathrm{Sr}$ ratios (Fig. 5) reach a minimum of 0.70427 at 83 mbsf. This value is similar to the ${ }^{87} \mathrm{Sr} /{ }^{86} \mathrm{Sr}$ ratios of both the silicate and leachable fractions of the solid sediment (Table 5 and Fig. 5). Below, the pore-water ${ }^{87} \mathrm{Sr} /{ }^{86} \mathrm{Sr}$ ratios increase progressively to 0.707 at $322 \mathrm{mbsf}$, in the chalk of Unit III. At $322 \mathrm{mbsf}$ the ${ }^{87} \mathrm{Sr} /{ }^{86} \mathrm{Sr}$ ratio of carbonate is similar to that of contemporaneous seawater. From 361 to $500 \mathrm{mbsf}$, the ${ }^{87} \mathrm{Sr} /{ }^{86} \mathrm{Sr}$ ratios of pore waters and leachable fraction are almost constant around 0.7070 , which is lower than ${ }^{87} \mathrm{Sr} /{ }^{86} \mathrm{Sr}$ ratios of contemporaneous seawater.

These concentrations and isotopic compositions are very unusual. For all of the DSDP-ODP sites, only several recent legs report comparable concentration gradients in volcaniclastic formations: Leg 126 (Sites 792 and 793; Egeberg et al., 1990b), Leg 134 (Sites 832 and 833; Collot, Greene, Stokking, et al., 1992), and Leg 135 (Site 841; Parson, Hawkins, Allan, et al., 1992; Blanc et al., 1991). The characteristics that these sites have in common with Unit II at Site 802 are the age, the fresh volcaniclastic compounds, and the high sedimentation rates. The main difference is the geodynamic context, which is forearc or intra-arc for Legs 126, 134, and 135. 

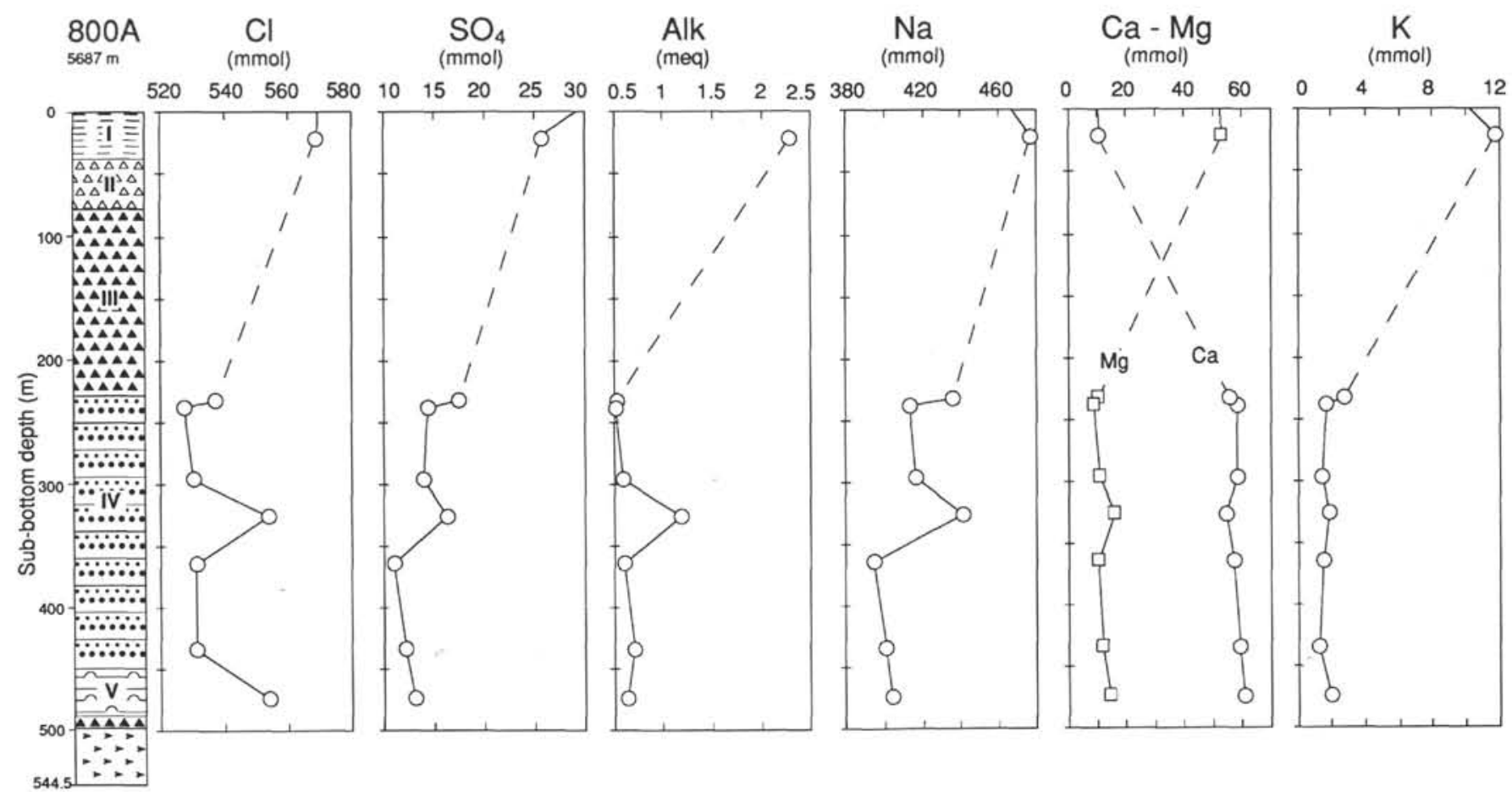

Figure 2. Distribution with depth of chloride, sulfate, alkalinity, sodium, calcium, magnesium, potassium, silica, manganese, boron, lithium, strontium, and ${ }^{87} \mathrm{Sr} /{ }^{86} \mathrm{Sr}$ in pore fluids of Site 800. The contemporaneous seawater curve for the Sr isotope ratio is drawn after Koepnick et al. (1985). Lithologic legend in Figure 4.

\section{DISCUSSION}

At all sites the interstitial water depth profiles present the classical depletion in $\mathrm{Mg}, \mathrm{K}, \mathrm{Na}, \mathrm{SO}_{4}$, and alkalinity, and enrichment in $\mathrm{Ca}$. This variation with depth has been described at numerous DSDP-ODP sites. It results from the superimposed effects of (1) diffusion between upper crustal basalts undergoing alteration, and (2) in-situ reactions of volcanogenic sediment to clays and zeolites (e.g., Kastner and Gieskes, 1976; McDuff, 1981). At these three sites, the ${ }^{87} \mathrm{Sr} /{ }^{86} \mathrm{Sr}$ ratios of interstitial water are always lower than those of contemporaneous seawater except for the topmost samples and the bottom one at Site 801 (Fig. 3). Low ${ }^{87} \mathrm{Sr} /{ }^{86} \mathrm{Sr}$ ratios confirm the major role of basaltic alteration. In both cases reactions of basaltic material, which is altered to smectites and zeolites (phillipsite and clinoptilolite), are involved. These reactions release $\mathrm{Ca}$ and consume $\mathrm{Mg}, \mathrm{Na}$, and $\mathrm{K}$ from the interstitial water. Similar secondary mineralogy and chemical variation of pore waters are observed on experimental alteration of basalts at low temperature (e.g., Crovisier et al., 1987; Crovisier, 1989). The interstitial water chemistry of each site provides evidence for specific processes involving alteration of basaltic matter either within the sediments or in the underlying basalts, and other diagenetic reactions.

We examine the Sr budget on the basis of two main processes: (1) volcanic $\mathrm{Sr}$ release during alteration, which tends to lower the $\mathrm{Sr}$ isotope ratio, and (2) dissolution/recrystallization of biogenic tests, which releases $\mathrm{Sr}$ with an isotopic ratio of seawater contemporaneous to that of the sediment. The volcanic contribution to the $\mathrm{Sr}$ budget can be estimated from $\mathrm{Sr}$ isotope ratios of contemporaneous seawater and volcanic material (Hawkesworth and Elderfield, 1978):

$$
f_{\text {volcanic }}=\frac{\left({ }^{87} \mathrm{Sr} /{ }^{86} \mathrm{Sr}\right)_{\text {seawater }}-\left({ }^{87} \mathrm{Sr} /{ }^{86} \mathrm{Sr}\right)_{\text {interstitial }}}{\left({ }^{87} \mathrm{Sr} /{ }^{86} \mathrm{Sr}\right)_{\text {seawater }}-\left({ }^{87} \mathrm{Sr} /{ }^{86} \mathrm{Sr}\right)_{\text {volcanic }}} \times 100
$$

The input of biogenic $\mathrm{Sr}$ can be estimated from the $\mathrm{Sr}$ content budget:

$$
\sum \mathrm{Sr}_{\text {interstitial }}=\mathrm{Sr}_{\text {seawater }}+\mathrm{Sr}_{\text {volcanic }}+\mathrm{Sr}_{\text {biogenic }} \text {. }
$$

The biogenic contribution to $\mathrm{Sr}$ is, therefore,

$$
f_{\text {biogenic }}=\frac{\sum \mathrm{Sr}-\mathrm{Sr}_{\text {seawater }}-\left(f_{\text {volcanic }} \times \sum \mathrm{Sr}\right)}{\sum \mathrm{Sr}} \times 100 .
$$

\section{Site $\mathbf{8 0 0}$}

Distinctive features of the concentration profiles from Site 800 are (1) the break in slope at the chert and porcellanite unit and (2) the low chlorinity of most samples from the volcaniclastic unit. The changes in gradients are certainly due to the presence of the chert, which reduces diffusional communication. The chert unit corresponds to logging Unit 1, characterized by 6- to 9-ohm-m resistivities, which are high compared with those of other formations ( 0.5 to $3 \mathrm{ohm}-\mathrm{m}$ in lithologic Units III and IV) (see "Downhole Measurements" section, "Site 800" chapter, Lancelot, Larson, et al., 1990). Chert porosity is $10 \%-30 \%$, whereas it is $30 \%-60 \%$ in the volcaniclastic sediments ("Physical Properties" section, "Site 800" chapter, 1990). Both high resistivity and low porosity imply a low diffusion constant in this unit. These results confirm the role of lithologic barriers to diffusion, which was already described for similar examples of chert over volcaniclastic units (DSDP Sites 315 and 317-Gieskes, 1976; DSDP Site 462-Gieskes and Johnson, 1981).

\section{Diagenesis or Diffusion from the Basaltic Crust?}

Under the chert barrier the interstitial water concentrations result from the combined effect of diffusion from basaltic crust and in-situ diagenetic reactions. The existence of $i n$-situ reactions is indicated by two observations:

1. Unit IV is composed mainly of fresh and altered volcaniclastic material, including glass, which is unstable (e.g., Gislason and Eugster, 1987). Authigenic smectites and zeolites (phillipsite and clinop- 

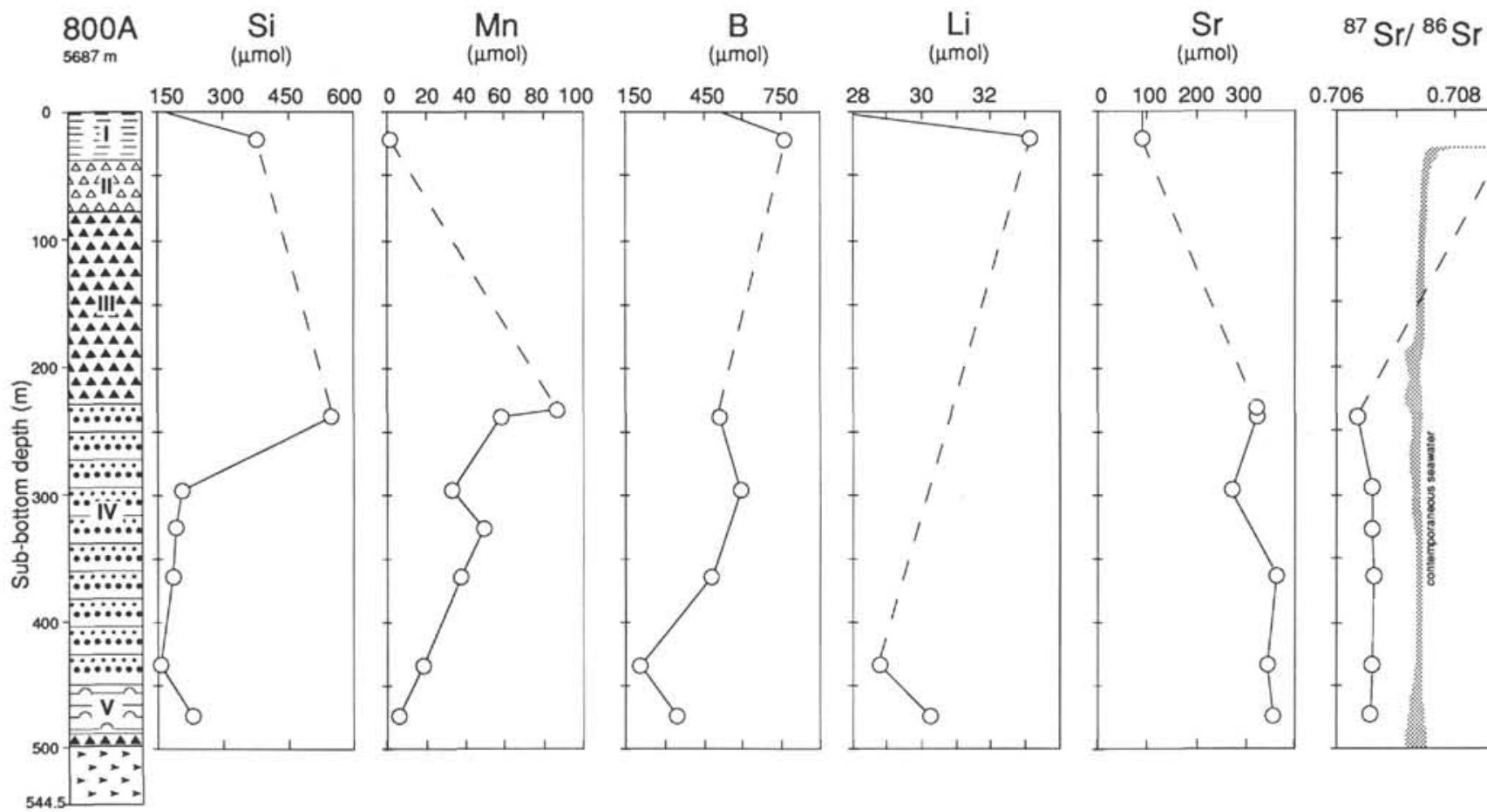

Figure 2 (continued).

tilolite) are abundant (Karpoff, this volume). The formation of such minerals from volcanic minerals (pyroxene, plagioclase, etc.) or glass consumes $\mathrm{Mg}, \mathrm{Na}$, and $\mathrm{K}$ and releases $\mathrm{Ca}$. In this case the alkalinity sink results from calcite precipitation in response to the increase in $\mathrm{Ca}$ concentration. Such reactions also lower the ${ }^{87} \mathrm{Sr} /{ }^{86} \mathrm{Sr}$ ratio of interstitial water, as volcanic $\mathrm{Sr}$ with a $\operatorname{low}^{87} \mathrm{Sr} /{ }^{86} \mathrm{Sr}$ ratio is released (e.g., Hoffert et al., 1978).

2. The concentration profiles are not straight, contrary to what is expected for nonreacting sediments. Concentrations of $\mathrm{Na}, \mathrm{SO}_{4}, \mathrm{Cl}$, and, to a lesser extent, $\mathrm{Mg}$, and $\mathrm{K}$ are significantly less depleted at 232,327 , and, for some elements, $473 \mathrm{mbsf}$. The $\mathrm{Ca}$ and $\mathrm{Sr}$ contents are lower at 232 and 327 mbsf. This is correlated with mineralogical and chemical differences in the sediments. At 232 and $473 \mathrm{mbsf}$, quartz is more abundant, with $\mathrm{SiO}_{2}$ at 64.7 and 81.2 weight percent (wt\%), respectively, instead of 43 to $53 \mathrm{wt} \%$, as in the rest of the sequence (Table 3 ). The observed mineralogy is not, however, completely consistent with the Na profiles. Interstitial waters below 327 mbsf are the most depleted in Na. If we correct the depletion for a possible effect of dilution by low-salinity water (see the following discussion), the decrease in $\mathrm{Na}$ is approximately $20 \mathrm{mmol} / \mathrm{L}$ with respect to seawater. $\mathrm{Na}$ loss is usually due to Na-zeolite formation; however, zeolites have not been detected by XRD analysis in these samples (Table 2). Karpoff (this volume) reports a minor occurrence of clinoptilolite in the upper section of the unit. The observed chemical trends may correspond only to very minor changes in the mineralogy of the sediment (e.g., Egeberg et al., 1990a). The observed depletion of Na could result from the neoformation of only 1 to $5 \mathrm{wt} \%$ of zeolite, depending on the exact stoichiometry of the reaction and the porosity. A small amount of zeolite could be difficult to observe by XRD. The Na profile may also be the result of diffusion from the basaltic crust, as pore waters from basaltic crust are depleted in $\mathrm{Na}$ (Mottl and Gieskes, 1990).

\section{Sr Budget}

For the samples of the volcaniclastic sediments of Site $800, f_{\text {volcanic }}$ varies between 19 and $25 \mathrm{~mol} \%$ for a volcanic ratio of 0.7035 .
Figure 6 shows that the $\mathrm{Sr}$ content is higher than can be predicted for a simple model of dissolution of basalt in seawater. The Cretaceous Sr content of seawater is not known (e.g., Holland, 1978), which adds a major uncertainty to budget calculations. Assuming that the initial Sr content of the interstitial water was $85 \mu \mathrm{mol}, f_{\text {biogenic }}$ should be around $50 \mathrm{~mol} \%$ (i.e., $150 \mu \mathrm{mol}$ is biogenic). This is a minimum estimate because the $\mathrm{Sr}$ uptake in secondary smectites is not included. The minimum amount of carbonate recrystallization can be calculated. Manheim and Sayles (1974) estimate that biogenic carbonates lose about 1000 parts per million (ppm) $\mathrm{Sr}$ as a consequence of recrystallization. Therefore, in a sediment with $25 \mathrm{wt} \%$ interstitial water, the $150 \mu \mathrm{mol} \mathrm{Sr}$ of biogenic origin requires the recrystallization of $\approx 0.5 \mathrm{wt} \%$ calcite in the solid sediment. This is compatible with the $\mathrm{CaCO}_{3}$ content in the sediment between 229 and 434 mbsf ( 0.5 to 10 wt \%, Table 4 ; "Site 800 " chapter, Lancelot, Larson, et al., 1990). In the radiolarite of Unit $\mathrm{V}$, the $\mathrm{CaCO}_{3}$ content is less than 0.2 wt\%; however, recrystallization of this small concentration could still produce a biogenic fraction of $50 \mathrm{~mol} \%$ because of the low pore-water content $(<5 \mathrm{wt} \%)$.

\section{Chlorine Depletion}

Four of the five samples from Unit IV are depleted in $\mathrm{Cl}$ by about $6 \%$ with respect to seawater. The chloride ion is conservative in marine sediments because there are no significant sinks or sources (e.g., Sayles and Manheim, 1975). Contamination by drilling mud being excluded, such a depletion is due to dilution by low-chlorinity water. Sources of fresh water are probably local because the depletion is not uniform in the Unit IV. Several sources may be proposed:

1. Dehydration related to diagenetic reactions such as organic matter degradation, smectite to illite reaction, gypsum to anhydrite conversion, or opal-A/opal-CT/quartz transitions. Based on the mineralogical composition of Unit IV, none of these reactions is likely to produce sufficient amounts of water in this context. Illite is not observed by XRD in this unit (Karpoff, this volume) and temperatures of Unit IV $\left(10^{\circ}-18^{\circ} \mathrm{C}\right.$; A. Fisher, pers. comm., 1991) are to low for 


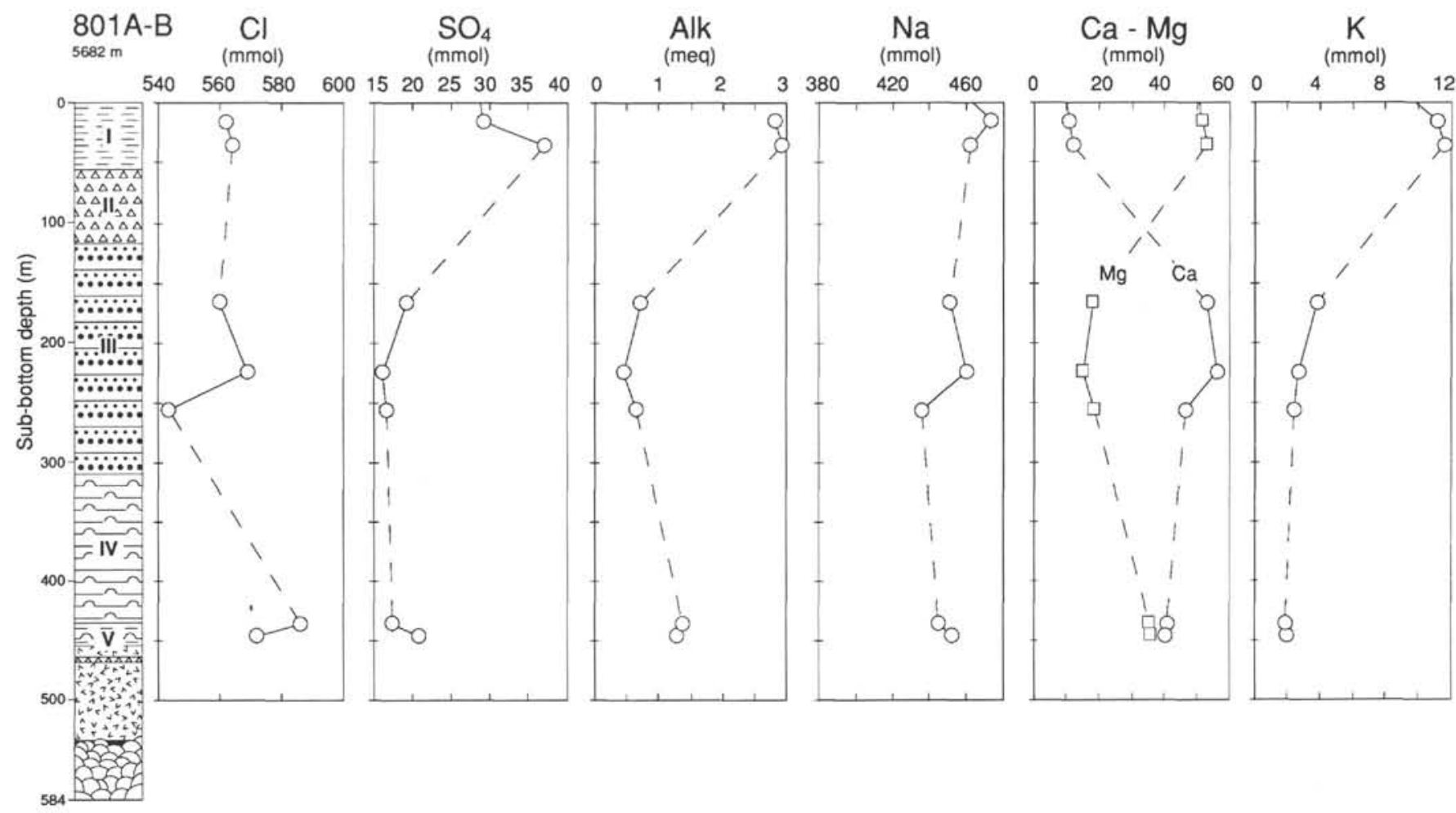

Figure 3. Distribution with depth of chloride, sulfate, alkalinity, sodium, calcium, magnesium, potassium, silica, manganese, boron, lithium, strontium, and ${ }^{87} \mathrm{Sr} /{ }^{86} \mathrm{Sr}$ in pore fluids of Site 801. The contemporaneous seawater curve for the Sr isotope ratio is drawn after Koepnick et al. (1985, 1990). Lithologic legend in Figure 4.

this type of reaction (Dunoyer de Segonzac, 1970). Opal-A/opal$\mathrm{CT} /$ quartz transitions are unlikely because silica phases are rare in Unit IV (Karpoff, this volume); moreover, the levels where $\mathrm{SiO}_{2}$ is abundant (232 and $473 \mathrm{mbsf}$ ) do not show significant $\mathrm{Cl}$ depletions.

2. Ion filtration processes could retain chloride ions in a clay-rich formation and produce low-chlorinity water (Hanshaw and Coplen, 1973), which could percolate into the sampled area. This seems unlikely because no Cl-rich waters have been observed.

3. Interlayer water expulsion under burial compaction from smectite-type minerals (e.g., Burst, 1976; Bird, 1984). This process is difficult to demonstrate, as there are no verifiable measurement of sorbed water. The effect of interlayer dewatering on pore water depends on the porosity and on the interlayer water content of the clay. For example, to generate the measured freshening ( 560 to $530 \mathrm{mmol}$ $\mathrm{Cl}$ ) it would be necessary to release $8.5 \mathrm{~g} \mathrm{H}_{2} \mathrm{O} / \mathrm{kg}$ of sediment for a pore-water content of $15 \mathrm{wt} \%$ and $20 \mathrm{~g} \mathrm{H}_{2} \mathrm{O} / \mathrm{kg}$ for a pore-water content of $35 \mathrm{wt} \%$. The interlayer water content of smectite $(i)$ is difficult to determine. According to Bird (1984) it is variable with confining pressure and temperature. In the conditions of Unit IV it can be estimated to be between 15 and 20 dry wt $\%$. Figure 7 illustrates the relative loss of interlayer water necessary to freshen pore water by $6 \%$ as a function of the final pore-water content. This calculation is for sediment with $90 \mathrm{wt} \%$ smectite, and $i$ has been fixed at 15 and 20 dry wt\% (Bird, 1984; Newman, 1987, chapter 5, p. 257).

This process is strongly dependent on the porosity. Estimates of pore-water contents have been made for two smectite-rich samples on the basis of measurement of total water content (pore water + interlayer water + adsorbed water) (France-Lanord and Sheppard, this volume). The estimates of pore-water content are $42.7-40.4 \mathrm{wt} \%$ at $327 \mathrm{mbsf}$ and $23.7-20.6 \mathrm{wt} \%$ at $364 \mathrm{mbsf}$, assuming values of $i=15$ and $20 \%$ dry wt $\%$, respectively, and $90 \mathrm{wt} \%$ of smectite in the sediment. A $6 \%$ chlorinity decrease would require a release of $7 \%-10 \%$ of the initial interlayer water at $364 \mathrm{mbsf}$ and $18 \%-21 \%$ at $327 \mathrm{mbsf}$ (Fig. 7).
In this context, the dewatering of interlayer water of smectite is a likely source of fresh water. Small losses of interlayer water (5\%$10 \%$ ) may explain the decrease in $\mathrm{Cl}$ content of interstitial water in samples that are smectite-rich and have low porosity. At 327 mbsf the porosity is too high and no decrease of $\mathrm{Cl}$ concentration is observed. At 232 and 473 mbsf, where $\mathrm{SiO}_{2}$ is more abundant (64.7 and $81.2 \mathrm{wt} \%$, Table 3 ), the chlorinity reduction is only $4 \%$ and $1.5 \%$, respectively. This process is not frequently observed in similar deep-sea sediments; it has been proposed for ODP Site 765 (Ludden, Gradstein, et al., 1990) and inferred as a deep source of fresh water in the Barbados accretionary complex (Tribble, 1990; Gieskes et al., 1990; Vrolijk et al., 1991). At Site 800, the chert of Unit III prevents diffusion, which helps to maintain the differences in concentration. This, combined with a relatively low pore-water content (10-15 $\mathrm{wt} \%$ ) and high smectite content, is a factor in increasing the effect of the reaction.

\section{Site 801}

\section{Diffusion Barriers and Alteration of the Jurassic Crust}

Interstitial water depth profiles at Site 801 are far from simple diffusion profiles. Between 0 and 300 mbsf the chemical change is relatively similar to that at Site 800 . A change in slope for nearly all chemical profiles occurs between Units I and III, which are separated by $60 \mathrm{~m}$ of chert-rich sediments. Low diffusion constants in the chert are indicated by the high sediment resistivities ( 2 to $10 \mathrm{ohm}-\mathrm{m})$ and low porosities (8\%-20\%) (see "Physical Properties" and "Downhole Measurements" sections, "Site 800" chapter, Lancelot, Larson, et al., 1990). Interstitial water in the volcaniclastic Unit III is depleted in $\mathrm{Mg}, \mathrm{K}, \mathrm{SO}_{4}$, alkalinity, $\mathrm{B}$, and $\mathrm{Li}$, and enriched in $\mathrm{Ca}$ and $\mathrm{Sr}$. The ${ }^{87} \mathrm{Sr} /{ }^{86} \mathrm{Sr}$ ratios are also lowered compared with that of contemporaneous seawater. The volcanic contribution to $\mathrm{Sr}$ is estimated to be at 20 to $25 \mathrm{~mol} \%$ (Fig. 6). All of these compositions are typical of an alteration reaction of material of basaltic origin. 


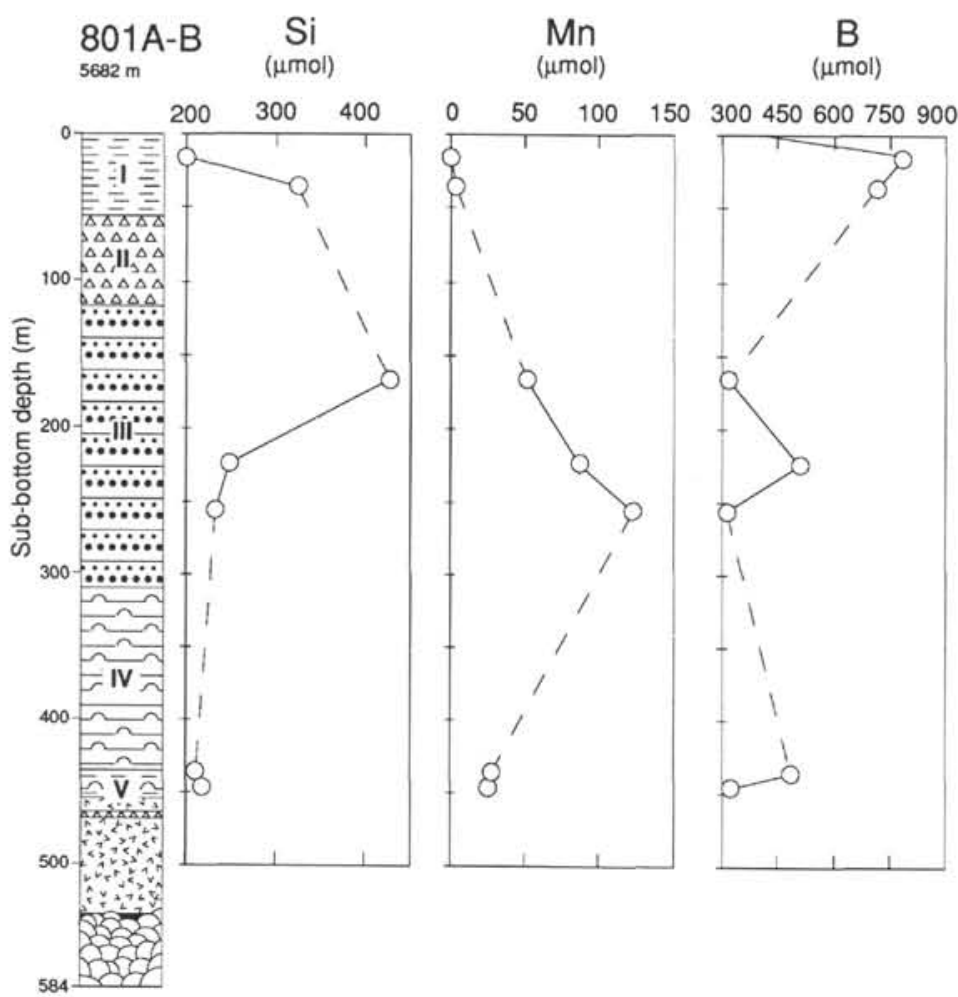

\section{$\mathrm{Li}$}

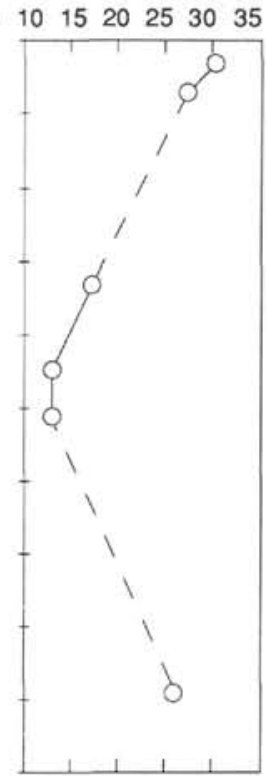

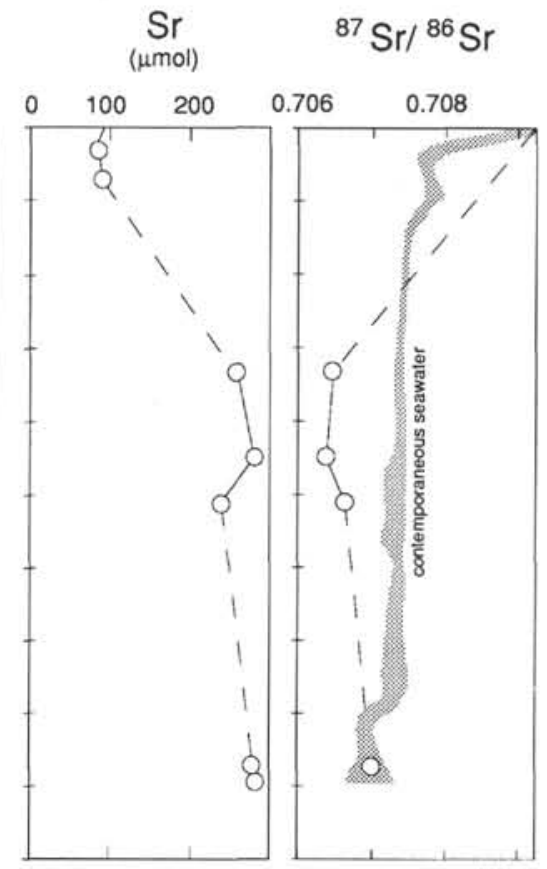

Figure 3 (continued).

From Units III to $\mathrm{V}$, there is a reverse evolution of $\mathrm{Ca}, \mathrm{Mg}$, and alkalinity contents and the $\mathrm{Sr}$ isotope ratio. The waters in Unit $\mathrm{V}$ are less modified compared to seawater than those in Unit III. This change in gradients between Units III and V is important because, first, it implies that the interstitial water chemistry in volcaniclastic Unit III is mainly controlled by in-situ reactions rather than by diffusion from the basement. Second, the small effect of volcanic alteration on interstitial waters only $50 \mathrm{~m}$ above the basement suggests that the basaltic crust is not undergoing active low-temperature alteration. The petrographic and geochemical study of the underlying basalts (Alt et al., this volume) shows that significant alteration is limited to the alkali basalts and the upper $20 \mathrm{~m}$ of the tholeiitic basalts and is mainly related to low-temperature hydrothermal circulation. Below $540 \mathrm{mbsf}$ the basalts are remarkably fresh. For instance, the $\mathrm{H}_{2} \mathrm{O}^{+}$content of the basalts never exceeds $1.5 \mathrm{wt} \%$, and the $\delta^{18} \mathrm{O}$ values of the whole-rock basalts are between $6 \%$ and $8 \%$, little enriched in ${ }^{18} \mathrm{O}$ (e.g., Muelenbach, 1986). Based on a positive covariation between age and $\delta^{18} \mathrm{O}$ of deep-sea basalts, Muelenbach $(1980,1986)$ concluded that lowtemperature alteration is a continuous process and persists even after sediment deposition. This has been confirmed by the interstitial water chemistry in sediments (Lawrence and Gieskes, 1981). At Site 801, the restricted diffusion through the sediments may partially explain the limited aging alteration of the basalts. In addition to the chert of Unit II, the radiolarite of Unit IV is a thick barrier for diffusion. Especially between 330 and 400 mbsf, relatively low porosities ( 2.5 to $10 \mathrm{vol} \%)$ and high resistivities $(\approx 5 \mathrm{ohm}-\mathrm{m})$ have been measured ("Site 801" chapter, Lancelot, Larson, et al., 1990).

\section{Diagenetic Reactions}

Interstitial waters in Unit III are almost isolated by their position between the chert and the radiolarite; hence, their chemistry is principally controlled by diagenetic reactions. The chemical changes of major ions is broadly similar to what is observed in the Site 800 volcaniclastic sediments. The main differences are (1) the Na concen- trations are constant indicating that $\mathrm{Na}$ is not incorporated in the secondary phases, and (2) the stability of $\mathrm{Cl}$ in Unit III except for a slight dip at $265 \mathrm{mbsf}(543 \mathrm{mmol})$. The mineralogy of secondary minerals is also different from that of Unit IV of Site 800 (Table 2). Here, zeolites are rare and celadonite is dominant with smectite. At 175 and 233 mbsf, celadonite and/or opal are dominant (Tables 2 and 3 ); hence, interlayer water release cannot have a reduced salinity. It is only at 265 mbsf, where smectite is dominant, that a slight freshening of pore water is observed.

In Unit III the volcanic Sr represents 20 to $25 \mathrm{~mol} \%$ of the total $\mathrm{Sr}$ and the $\mathrm{Sr}$ budget implies a biogenic carbonate contribution (Fig. 6). The $\mathrm{CaCO}_{3}$ content of the sediment is $4-8 \mathrm{wt} \%$, which is much higher than required by the preceding carbonate recrystallization model. In Unit V the volcanic Sr contribution is negligible, -3.5 to 4 mol\% depending on the $\mathrm{Sr}$ isotope ratio of the contemporaneous seawater. The absence of volcanic contribution is consistent with the absence of volcanic detritus in the sediment, the red clay being of authigenic origin (Karpoff, this volume). Assuming a Sr concentration of $85 \mu \mathrm{mol}$ for Jurassic seawater, the $\mathrm{Sr}$ concentration implies a $\mathrm{Sr}$ input of $\approx 200 \mu \mathrm{mol} / \mathrm{L}$. The $\mathrm{CaCO}_{3}$ content of the sediment $(<0.2$ $\mathrm{wt} \%$ ) is too low to account for $\mathrm{Sr}$ input by carbonate recrystallization. $\mathrm{Sr}$ may be released by dissolution of radiolarite tests, such as Acantharia, which contain $\mathrm{Sr}$ (Odum, 1951). An alternative is that $\mathrm{Sr}$ is released from authigenic smectite during diagenetic modifications with increasing burial and age (Clauer et al., 1975; 1982).

\section{Site $\mathbf{8 0 2}$}

The concentration gradients in the first hundred meters of Hole $802 \mathrm{~A}$ are among the highest ever recorded in a DSDP-ODP hole. Between 44 and $83 \mathrm{mbsf}$, both $\mathrm{Cl}$ and $\mathrm{Ca}$ increase by $83 \mathrm{mmol} / \mathrm{L}$, $\mathrm{SO}_{4}, \mathrm{Mg}, \mathrm{K}, \mathrm{B}$, and $\mathrm{Li}$ are reduced to almost zero, and the ${ }^{87} \mathrm{Sr}{ }^{86} \mathrm{Sr}$ ratio drops down to 0.704 . Mechanisms that can raise the $\mathrm{Cl}$ concentration in interstitial waters are the dissolution of evaporites, ultrafiltration and the uptake of water in secondary minerals, or formation 


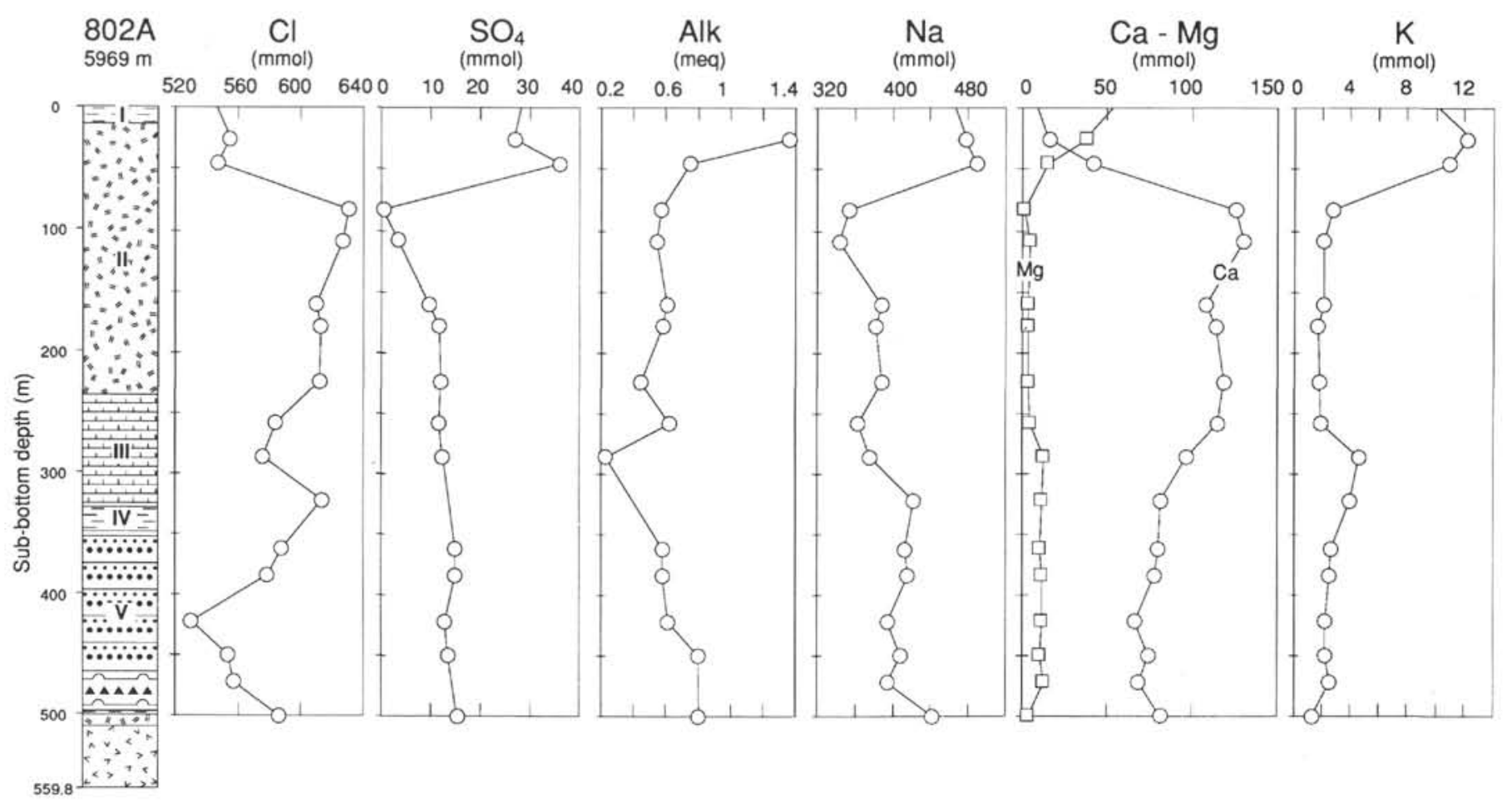

Figure 4. Distribution with depth of chloride, sulfate, alkalinity, sodium, calcium, magnesium, potassium, pH, silica, manganese, boron, and lithium in pore fluids at Site 802.

of gas hydrates. The parallel evolution of the other ions, the $\mathrm{Sr}$ isotope ratios, the volcanic nature of the primary material, and the secondary paragenesis rich in smectites and zeolites clearly indicate that alteration of volcanic ash into secondary hydrous minerals is the process that enhances the $\mathrm{Cl}$ content by water uptake. Analogously high $\mathrm{Cl}$ and $\mathrm{Ca}$ concentrations recently found at Sites 792 and 793 has been attributed to alteration reactions in the volcaniclastic sediments (Egeberg et al., 1990a).

Concentrations reach high and low extremes at 80-100 mbsf and reversed evolution are observed below this level, just below the Miocene tuffs. This implies that significant diagenetic reactions are only active in the tuff between 50 and 100 mbsf. Below the tuff, most concentration profiles are constant and similar to what is observed in volcaniclastic units at Sites 800 and 801 . The fact that the ${ }^{87} \mathrm{Sr} /{ }^{86} \mathrm{Sr}$ ratios of the interstitial waters and the leachate fraction (mainly carbonates) in volcaniclastic Unit V are similar, and that the values are lower than that of contemporaneous seawater (Fig. 5), imply an equilibrium of carbonates with altered pore waters.

\section{Closed System Evolution?}

In the 40 to $80 \mathrm{mbsf}$ interval, the concentration gradients are extremely high, up to $2.3 \mathrm{mmol} / \mathrm{m}$ for $\mathrm{Ca}$ and $\mathrm{Cl}$ (Fig. 4). The existence of high gradients in 10- to 15-m.y.-old sediments implies either (1) that reactions are going on rapidly now (but there is no reason why alteration should have started only recently) or (2) that the tuffs rapidly become a "closed system" because of the high accumulation rate and high cementation of the sediments, which limit diffusive transport. Overall sedimentation rates in the Miocene tuffs are at least $25 \mathrm{~m} / \mathrm{m}$.y. ("Site 802" chapter, Lancelot, Larson, et al., 1990) which is not especially high. However, the type of deposit, mass flows intercalated by pelagic intervals (Cores 129-802A-13R and -19R), suggests that accumulation rates were higher between pelagic deposition periods. No downhole measurements are available for evaluating diffusion properties in the upper 100 mbsf. Nevertheless, between 100 and 140 mbsf resistivities are highly variable between 2 and $200 \mathrm{ohm}-\mathrm{m}$ at
121-124 mbsf ("Site 802" chapter, Lancelot, Larson, et al., 1990). These high resistivity levels correspond to intervals of coarse sandy tuff well cemented by silicates. At the same level, sonic velocities reach $4 \mathrm{~km} / \mathrm{s}$. This is much higher than the mean for all sandstone and tuff samples collected during Leg 129 ( 2.5 to $2.8 \mathrm{~km} / \mathrm{s}$; Fisher et al., this volume) and also indicates a high degree of cementation. Intervals with a low diffusion constant are therefore likely in the upper part of the unit because a similar lithology is present.

\section{Alteration Budget}

Following Egeberg et al. (1990a) it is possible to estimate the degree of alteration of the sediment from the $\mathrm{Cl}$ increase, assuming that $\mathrm{Cl}$ is not incorporated in the minerals and that the system is closed. Such a crude estimate depends on (1) the water content of the secondary phases (assumed to be between 20 and $26 \mathrm{wt} \%$ for a mixture of smectite and zeolites) and (2) the initial porosity. This last parameter is related to the degree of alteration and to the final porosity. The shipboard measurements of the sediment water content between 25 and $235 \mathrm{mbsf}$ is 22 to $59 \mathrm{wt} \%$ (average $=32 \mathrm{wt} \%$ ). These data overestimate the real interstitial water content because all or part of the interlayer water of smectites and the channel water of zeolites is included in the measure. If smectites and zeolites represent about 20 wt $\%$ of the solids, the overestimate may reach $5 \mathrm{wt} \%$ of the sediment. A reasonable value for average interstitial water content is, therefore, $28 \mathrm{wt} \%$ and the upper limit is $40 \mathrm{wt} \%$. Figure 8 shows the relation between the degree of alteration and the $\mathrm{Cl}$ content of the interstitial water for interstitial water contents at 25 and $40 \mathrm{wt} \%$ and water contents in the secondary minerals of 20 and $26 \mathrm{wt} \%$. Taking into account the large uncertainties, an increase of $85 \mathrm{mmol}$ of the $\mathrm{Cl}$ content could be achieved by the alteration of 20 to $50 \mathrm{wt} \%$ of the solids, with the most plausible values at about $20 \mathrm{wt} \%$. This is consistent with the shipboard core descriptions, which estimate the proportion of smectite, zeolite, and calcite at $20 \%$ of the tuffs. This estimate represents the average alteration of Unit II, but at a specific level secondary minerals may represent anywhere from 5\% to $95 \%$ 


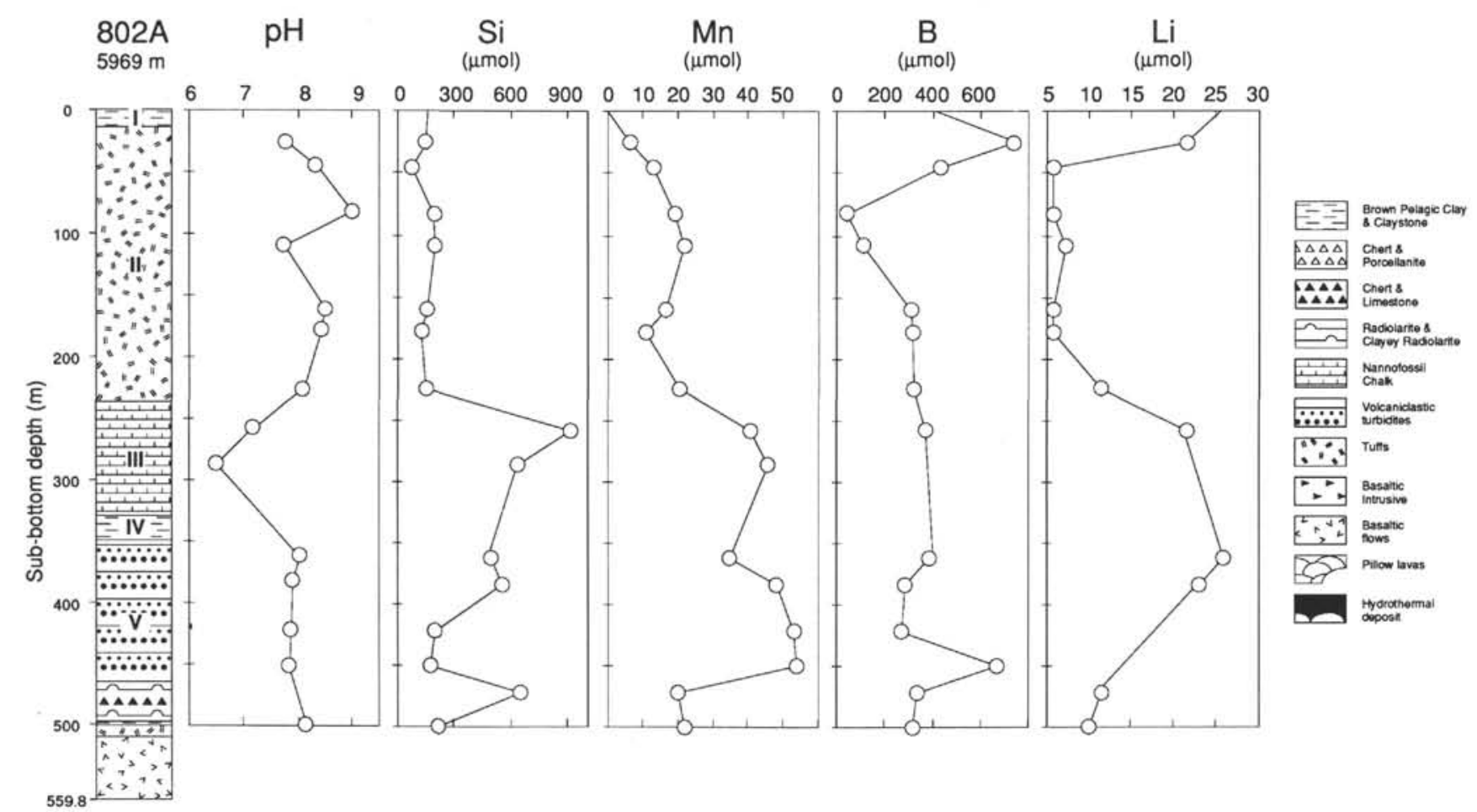

Figure 4 (continued).

of the sediment. For instance, at $83 \mathrm{mbsf}$ only magnetite is visible by XRD determination and basaltic glass is certainly higher than $80 \%$ (Table 2). The consistency of the calculated degree of alteration and the observed proportion of altered minerals supports the hypothesis that Unit II behaves like a nearly closed system and that the water/rock ratio remains very low. The conditions for such a sedimentary system are high accumulation rates and low diffusion properties.

The upper part of Unit II ( $<110 \mathrm{mbsf})$ is depleted in $\mathrm{Sr}$ compared with the curve for basalt dissolution (Fig. 6). This may be due to lower concentration of $\mathrm{Sr}$ in Miocene seawater and/or of the ${ }^{87} \mathrm{Sr} /{ }^{86} \mathrm{Sr}$ ratio of volcanic matter. For a system with considerable volcanic contribution, the ${ }^{87} \mathrm{Sr} /{ }^{86} \mathrm{Sr}$ ratio of volcanic matter is very important. In the absence of direct measurement of the source, it has been fixed at 0.7035 . This is already a little lower than the value of 0.7038 measured for the silicate fraction of Sample 129-802A-10R-2, 140-150 cm (83 mbsf), where fresh basaltic glass is dominant. Therefore, if the initial $\mathrm{Sr}$ concentration was similar to that of modern seawater, the low $\mathrm{Sr}$ content at 83 and 109 mbsf implies that $\mathrm{Sr}$ is incorporated in secondary phases. The phases that take up $\mathrm{Sr}$ in the unit are probably smectite and carbonate. At 109 mbsf the whole-rock $\mathrm{Sr}$ concentration is very high (1484 ppm); however, the phase(s) that contains $\mathrm{Sr}$ has not been identified. Below $110 \mathrm{mbsf}$, the volcanic contribution starts to decrease and the $\mathrm{Sr}$ content continues to increase (Fig. 6). This is consistent with the progressive increase of the $\mathrm{CaCO}_{3}$ content of the sediment with depth in Subunit IIB and Unit III (Fig. 5). Nevertheless, even at 286 mbsf in almost pure chalk, the interstitial water is still depleted in ${ }^{87} \mathrm{Sr}$ compared with the marine composition of the carbonates.

In systems of slowly accumulating sediments, $\mathrm{Ca}$ is removed from the sediment and $\mathrm{Mg}$ is continuously added from seawater as an effect of diffusional exchange (e.g., Perry et al., 1976). For the same reason, $\mathrm{H}_{2} \mathrm{O}$ uptake in hydrous minerals is not visible and the $\mathrm{Cl}$ content of the fluid does not change significantly. The low water/rock ratio estimated for the alteration of the tuffs implies some chemical and mineralogical consequences for the evolution of the system. The $\mathrm{pH}$ value increases with depth ( 7.8 to 9.0$)$, similar to those described in basalt dissolution experiment at $0^{\circ} \mathrm{C}$ are also observed (Crovisier, 1989). The alteration of about $20 \mathrm{wt} \%$ of the initial basaltic glass should deliver 2000 to $4000 \mathrm{mmol}$ of $\mathrm{Ca}$ to the interstitial fluid. Calcium is reprecipitated in situ in phillipsite, clinoptilolite, and calcite (Karpoff et al., this volume), but the average Ca content of the sediment is $7 \mathrm{wt} \%$ (on dry total), which implies a significant extraction of calcium if the initial glass concentration was 10-12 wt \%. Part of this loss corresponds to $\mathrm{Ca}$ incorporated in fracture fillings, which are abundant between 50 and 150 mbsf and contain mainly a strange Ca-rich mineral named thaumasite (Karpoff et al., this volume). Thaumasite is also demonstrated to be the dominant sink for $\mathrm{SO}_{4}$ on the basis of $\delta^{34} \mathrm{~S}$ of interstitial water (Alt and Burdett, this volume). Another consequence of the low water/rock ratio should be low $\mathrm{Mg}$ enrichment. $\mathrm{Mg} / \mathrm{Al}$ molar ratios are between 0.9 and 1.1 in the 83-179 mbsf interval (pelagic clay excepted) compared with 0.94 to 1.9 in the volcaniclastic sediments of Sites 800 and 801 .

\section{CONCLUSIONS}

Studies of the chemistry and Sr isotope composition of interstitial water at Sites 800,801 , and 802 have revealed patterns related to the alteration of volcanic matter under conditions in which diffusive exchange with seawater is low. At Sites 800 and 801 and in volcaniclastic turbidites at Site 802 (Unit V), diagenetic reactions are limited and no $\mathrm{Cl}$ increase is observed. At Site 802 , the alteration of the Miocene tuffs induces water uptake in secondary minerals and a subsequent $\mathrm{Cl}$ rise. The composition of the volcanic sediment is roughly similar at the three sites; however, Site 802 shows some distinctive characteristics: lower temperature, high cementation, probably high accumulation rates, and younger age (Miocene for Site 802 and middle to Late Cretaceous for the volcaniclastic turbidites at Sites 801,801 , and 802 ). Both high accumulation rates and cementation favor a "closed system" alteration of the tuff since the deposition of the sediment. In contrast, at Sites 800 and 801 , prior to the development of chert sequences that sealed the system, no low-diffusion layer are present, and a low accumulation rate favored the high water/rock ratio alteration of the volcaniclastic sediment. This suggests that the volcaniclastic material at Sites 800 and 801 becomes almost "inert" compared with the Miocene tuffs at Site 802. 
The ages of the deposits are also an important factor in diffusion processes and it is possible that the gradients presently observed in the Miocene tuffs will be smoothed in 100 m.y., which is the age difference between the Miocene tuffs at Site 802 and the turbidites at Site 800 .

\section{ACKNOWLEDGMENTS}

Support for research was provided by a grant from CNRS ASP "Soutien ODP-France." "Un grand merci" to Valerie Clark and Scott Chaffey in the chemistry lab of the JOIDES Resolution, Danielle Dautel, and Luc Marin for chemical help, Louis Derry for "frenglish" deciphering and various scientific discussions, and Peter Vrolijk, Andy Fisher, and an anonymous reviewer for constructive comments. This is CRPG contribution no. 887.

\section{REFERENCES}

Alibert, C., Michard, A., and Albarède, F., 1983. The transition from alkali basalts to kimberlites: isotope and trace element evidence from melilites. Contrib. Mineral. Petrol., 82:176-186.

Bird, P., 1984. Hydration-phase diagrams and friction of montmorillonite under laboratory and geologic conditions, with implications for shale compaction, slope stability, and strength of fault gouge. Tectonophysics, 107:235-260.

Blanc, G., and ODP 135 Shipboard Scientific Party, 1991. Hydrogeochemistry of the Lau backarc basin and the Tonga forearc basin, ODP 135. Terra Abstract, 3:466.

Burst, J. F., 1976. Argillaceous sediment dewatering. Annu. Rev. Earth Planet. Sci., 4:293-318.

Clauer, N., Hoffert, M., Grimaud, D., and Millot, G., 1975. Compositions isotopiques du Sr d'eaux interstitielles extraites de sédiments récents: un argument en faveur de l'homogénéisation isotopique des minéraux argileux. Geochim. Cosmochim. Acta, 39:1579-1582.

Clauer, N., Hoffert, M., and Karpoff, A. M., 1975. The Rb-Sr isotope system as an index of origin and diagenetic evolution of southern Pacific red clays. Geochim. Cosmochim. Acta, 46:2659-2664.

Collot, J.-Y., Greene, H. G., Stokking, L. B., et al., 1992. Proc. ODP, Init. Repts., 134: College Station, TX (Ocean Drilling Program).

Crovisier, J. L., 1989. Dissolution des verres basaltiques dans l'eau douce: essai de modélisation [Thèse de Doctorat]. Univ. Louis Pasteur, Strasbourg.

Crovisier, J. L., Honnorez, J., and Eberhart, J. P., 1987. Dissolution of basaltic glass in seawater: mechanism and rate. Geochim. Cosmochim. Acta, 51:2977-2990.

Dunoyer de Segonzac, G., 1970. The transformation of clay minerals during diagenesis and low-grade metamorphism: a review. Sedimentology, 15:281-346.

Egeberg, P. K., Aagaard, P., and Craig Smalley, P., 1990a. Major element and oxygen isotope studies of interstitial waters: ODP Leg 113. In Barker, P. F., Kennett, J. P., et al., Proc. ODP, Sci. Results, 113: College Station, TX (Ocean Drilling Program), 135-146.

Egeberg, P. K., and the Leg 126 Shipboard Scientific Party, 1990b. Unusual composition of pore water found in the Izu-Bonin fore-arc sedimentary basin. Nature, 344:215-218.

Gieskes, J. M., 1976. Interstitial water studies, Leg 33, In Schlanger, S. O., Jackson, E. D., et al., Init. Repts. DSDP, 33: Washington (U.S. Govt. Printing Office), 563-570.

Gieskes, J. M., and Johnson, J., 1981. Interstitial water studies, Leg 61. In Larson, R. L., and Schlanger, S. O., Init. Repts. DSDP, 61: Washington (U.S. Govt. Printing Office), 603-605.

Gieskes, J. M., Vrolijk, P., and Blanc, G., 1990. Hydrogeochemistry of the Northern Barbados Accretionary Complex transect: Ocean Drilling Project Leg 110. J. Geophys. Res., 95:8809-8818.

Gislason, S. R., and Eugster, H. P., 1987. Meteoric water-basalt interaction I: a laboratory study. Geochim. Cosmochim. Acta, 51:2827-2840.

Hanshaw, B. B., and Coplen, T. B., 1973. Ultrafiltration by a compacted clayey membrane. II: Sodium ion exclusion at various ionic strengths. Geochim. Cosmochim. Acta, 37:2311-2327.

Hawkesworth, C. J., and Elderfield, H., 1978. The strontium isotopic composition of interstitial waters from Sites 245 and 336 of the Deep Sea Drilling Project. Earth Planet. Sci. Lett., 40:423-432.
Hoffert, M., Karpoff, A.-M., Clauer, N., Schaaf, A., Courtois, C., and Pautot, G., 1978. Néoformations et altérations dans trois faciès volcanosédimentaires du Pacific Sud. Oceanol. Acta, 1:187-202.

Holland, H. D., 1978. The Chemical Evolution of the Atmosphere and Oceans: Princeton, NJ (Princeton Univ. Press).

Kastner, M., and Gieskes, J. M., 1976. Interstitial water profiles and sites of diagenetic reactions, Leg 35, DSDP, Bellinghausen abyssal plain. Earth Planet. Sci. Lett., 33:11-20.

Koepnick, R. B., Burke, W. H., Denison, R. E., Hetherington, E. A., Nelson, H. F., Otto, J. B., and Waite, L. E., 1985. Construction of the seawater ${ }^{87} \mathrm{Sr} /{ }^{86} \mathrm{Sr}$ curve for the Cenozoic and Cretaceous: supporting data. Chem. Geol. (Isot. Geosci. Sect.), 58:55-81.

Koepnick, R. B., Denison, R. E., Burke, W. H., Hetherington, E. A., and Dahl, D. A., 1990. Construction of the Triassic and Jurassic portion of the Phanerozoic curve of seawater ${ }^{87} \mathrm{Sr} /{ }^{86} \mathrm{Sr}$. Chem. Geol. (Isot. Geosci. Sect.), 80:327-349.

Lancelot Y., Larson, R. L., et al., 1990. Proc. ODP, Init. Repts., 129: College Station, TX (Ocean Drilling Program).

Lawrence, J. R., and Gieskes, J. M., 1981. Constraints on water transport and alteration in the oceanic crust from the isotopic composition of pore water J. Geophys. Res., 86:7924-7934.

Ludden, J. N., Gradstein, F. M., et al., Proc. ODP, Init. Repts., 123: College Station, TX (Ocean Drilling Program).

Manheim, F. T., and Sayles, F. L., 1974. Composition of interstitial waters of sediments, based on deep-sea drill cores. In Goldberg, E. D. (Ed.), The Sea (Vol. 5): New York (Wiley), 527-568.

McDuff, E., 1981. Major cation gradients in DSDP interstitial water: the role of diffusive exchange between seawater and upper oceanic crust. Geochim. Cosmochim. Acta, 34:105-120.

McDuff, E., and Gieskes, J. M., 1976. Calcium and magnesium profiles in DSDP interstitial waters: diffusion or reaction? Earth Planet. Sci. Lett., 33:1-10.

Mottl, M. J., and Gieskes, J. M., 1990. Chemistry of water sampled from Oceanic Basement Borehole, 1979-1988. J. Geophys. Res., 95:9327-9342.

Muelenbach, K., 1980. The alteration and aging of the basaltic layer of the sea floor: oxygen isotope evidence from DSDP/IPOD Legs 51, 52, and 53. In Donnelly, T., Francheteau, J., Bryan, W., Robinson, W., Flower, M., Salisbury, M., et al., Init. Repts. DSDP, 51, 52, 53: Washington (U.S. Govt. Printing Office), 1159-1167.

1986. Alteration of the oceanic crust and the ${ }^{18} \mathrm{O}$ history of seawater. In Valley, J. W., Taylor, H. P., and O'Neil, J. R., Stable Isotope in High Temperature Geological Processes. Mineral. Soc. Am., Rev. in Mineral. Ser., 16:425-444.

Newman, A.C.D., 1987. The interaction of water with clay mineral surfaces. In Newman, A.C.D. (Ed.), Chemistry of Clays and Clay Mineral (Vol. 5): London (Longman Scientific and Technical), 237-274.

Odum, H. T., 1951. Notes on the strontium content of seawater, celestite, radiolaria, and strontianite snail shells. Science, 114:211.

Parson, L., Hawkins, J., Allan, J., et al., 1992. Proc. ODP, Init. Repts., 135: College Station, TX (Ocean Drilling Program).

Perry, E. A., Gieskes, J. M., and Lawrence, J. R., 1976. Mg, Ca and $\mathrm{O}^{18} / \mathrm{O}^{16}$ exchange in the sediment-pore water system, Hole 149, DSDP. Geochim. Cosmochim. Acta, 40:413-423.

Sayles, F. L., and Manheim, F. T., 1975. Interstitial solutions and diagenesis in deeply buried marine sediments: results from the Deep Sea Drilling Project. Geochim. Cosmochim. Acta, 39:103-127.

Smith, W.H.F., Staudigel, H., Watts, A. B., and Pringle, M. S., 1989. The Magellan Seamounts: Early Cretaceous record of the South Pacific isotopic and thermal anomaly. J. Geophys. Res., 94:10501-10523.

Tribble, J. S., 1990. Clay diagenesis in the Barbados Accretionary Complex: potential impact on hydrology and subduction dynamics. In Moore, J. C., Mascle, A., et al., Proc. ODP, Sci. Results, 110: College Station, TX(Ocean Drilling Program), 97-110.

Vrolijk, P., Fisher, A., and Gieskes, J., 1991. Geochemical and geothermal evidence for fluid migration in the Barbados accretionary prism (ODP Leg 110). Geophys. Res. Lett., 18:947-950.

Date of initial receipt: 3 June 1991

Date of acceptance: 6 January 1992

Ms 129B-124 


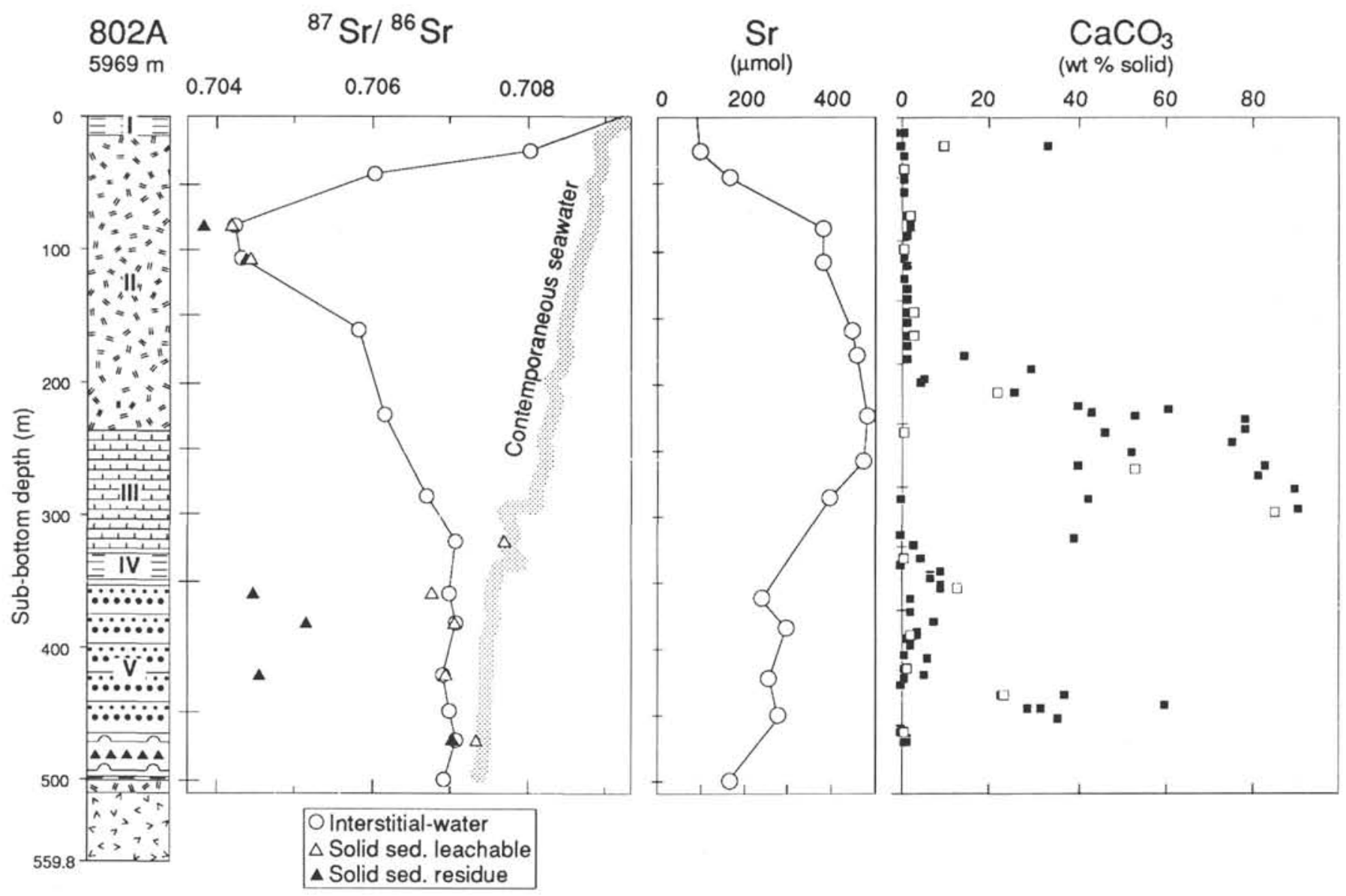

Figure 5. Site 802 distribution with depth of ${ }^{87} \mathrm{Sr} /{ }^{86} \mathrm{Sr}$ in pore fluids and in solid sediments, $\mathrm{Sr}$ in pore fluids, and $\mathrm{CaCO}_{3}$ in solid sediment. Data are from Tables 1, 4, and 5 and Lancelot, Larson, et al. (1990). The contemporaneous seawater curve for Sr isotope ratio is drawn after Koepnick et al. (1985). Lithologic legend in Figure 4. Open symbols on the $\mathrm{CaCO}_{3}$ plot are for the solid residue of interstitial water samples. 


\section{FRANCE-LANORD, A. MICHARD, A. M. KARPOFF}

Table 2. Lithologic description and X-ray determination of major minerals of interstitial water sample sediment.

\begin{tabular}{|c|c|c|c|c|c|c|c|c|c|c|}
\hline $\begin{array}{l}\text { Core, section, } \\
\text { interval }(\mathrm{cm})\end{array}$ & $\begin{array}{l}\text { Depth }{ }^{a} \\
\text { (mbsf) }\end{array}$ & Rock type & Quartz & Philipsite & Clinoptilolite & Analcime & Calcite & Smectite & $\begin{array}{l}\text { Volcanic } \\
\text { minerals }\end{array}$ & Others \\
\hline \multicolumn{11}{|l|}{$129-800 \mathrm{~A}-$} \\
\hline $4 \mathrm{R}-2,25-30$ & 22 & Pelagic brown clay & $x$ & $\mathrm{xx}$ & $x$ & - & - & $\mathrm{xx}$ & o & Illite $\mathrm{x}$ \\
\hline $26 \mathrm{R}-2,140-148$ & 232 & Volcaniclastic turbidite & $\mathrm{xx}$ & - & $\mathrm{xx}$ & - & $\mathrm{x}$ & $x x$ & o & \\
\hline $27 \mathrm{R}-1,140-150$ & 239 & Volcaniclastic turbidite & $\mathrm{x}$ & - & $\mathrm{xxx}$ & - & o & 0 & - & Celadonite $\mathrm{xx}$ \\
\hline $33 R-6,60-70$ & 296 & Volcaniclastic claystone & - & $\mathrm{xx}$ & - & - & $\mathrm{xx}$ & $x x x$ & o & \\
\hline $37 R-2,0-10$ & 327 & Volcaniclastic claystone & - & - & - & - & - & $x x x x x$ & - & \\
\hline $41 \mathrm{R}-2,0-10$ & 364 & Volcaniclastic sandstone & & - & - & - & - & o & $x x x x x$ & - \\
\hline $49 R-2,140-150$ & 434 & Volcaniclastic siltstone & - & - & - & - & - & $x x x x x$ & o & \\
\hline $54 \mathrm{R}-2,0-12$ & 473 & Clayey radiolarite & $\operatorname{xxxxx}$ & - & - & - & - & $\mathrm{xx}$ & - & Hematite o \\
\hline \multicolumn{11}{|l|}{$129-801 \mathrm{~A}-$} \\
\hline $3 R-2,145-150$ & 15 & Pelagic brown clay & $\mathrm{x}$ & $\mathrm{x}$ & - & - & - & $\mathrm{xxx}$ & - & Illite o \\
\hline $5 R-3,145-150$ & 36 & Pelagic brown clay & & \multicolumn{7}{|c|}{ No data } \\
\hline $19 \mathrm{R}-1,65-73$ & 167 & Siliceous silty claystone & o & - & $\mathrm{x}$ & - & o & $x$ & - & Opal-CT xxxx \\
\hline \multicolumn{11}{|l|}{$129-801 \mathrm{~B}-$} \\
\hline $5 R-2,0-10$ & 225 & Volcaniclastic silty claystone & o & - & $\mathrm{xx}$ & - & 0 & $\mathrm{xxx}$ & $\mathrm{x}$ & \\
\hline $8 \mathrm{R}-3,115-125$ & 257 & Volcaniclastic silty claystone & $x x$ & - & o & - & $\mathrm{x}$ & $\mathrm{xxx}$ & o & Celadonite o \\
\hline $33 \mathrm{R}-1,143-150$ & 436 & Metalliferous red clay & $\mathrm{xxxx}$ & - & - & - & - & $\mathrm{xx}$ & - & Hematite $\mathrm{x}$ \\
\hline $35 \mathrm{R}-2,0-10$ & 446 & Metalliferous red clay & $\mathrm{xxx}$ & - & - & - & - & $\mathrm{xxx}$ & - & Hematite $\mathrm{x}$ \\
\hline \multicolumn{11}{|l|}{$129-802 \mathrm{~A}-$} \\
\hline $4 \mathrm{R}-1,140-150$ & 26 & Brown volcanic ash-tuff & - & $x x$ & o & - & $\mathrm{x}$ & $x x$ & o & \\
\hline $6 \mathrm{R}-2,0-10$ & 44 & Black volcanic ash-tuff & - & $x$ & - & $\mathrm{xxx}$ & - & $\mathrm{xxx}$ & $\mathrm{xx}$ & Chabazite o \\
\hline $10 \mathrm{R}-2,140-150$ & 83 & Black volcanic ash-tuff & & \multicolumn{7}{|c|}{ No data } \\
\hline $13 R-1,53-58$ & 109 & Pelagic brown clay & - & o & $x x$ & - & - & $x x x$ & - & \\
\hline $19 \mathrm{R}-2,107-117$ & 162 & Volcanic ash-tuff & - & $x x x$ & - & $\mathrm{x}$ & - & $x x x$ & $\mathrm{xx}$ & \\
\hline $21 \mathrm{R}-1,103-110$ & 179 & Claystone & - & $\operatorname{xxxx}$ & - & o & - & $x x x$ & $\mathrm{xx}$ & \\
\hline $26 \mathrm{R}-1,0-10$ & 225 & Calcareous claystone & - & $\mathrm{xx}$ & - & - & $\mathrm{xxx}$ & $\mathrm{x}$ & $\mathrm{xx}$ & \\
\hline $29 \mathrm{R}-3,29-34$ & 258 & Pelagic brown clay & o & 0 & $\mathrm{xxx}$ & - & $\mathrm{x}$ & $\mathrm{xx}$ & $\mathrm{xx}$ & \\
\hline $32 \mathrm{R}-2,140-150$ & 286 & Nannofossil chalk & $\mathrm{x}$ & - & $\mathrm{x}$ & - & $x \times x$ & $x$ & - & Opal-CT xx \\
\hline $36 \mathrm{R}-1,80-88$ & 322 & Nannofossil chalk & $\stackrel{-}{-}$ & - & o & - & $x x x x x$ & - & - & Opal-CT x \\
\hline $40 \mathrm{R}-2,140-150$ & 361 & Volcaniclastic turbidite & $\mathrm{x}$ & - & o & - & - & $\mathrm{x}$ & $x x x$ & \\
\hline $43 \mathrm{R}-1,140-150$ & 384 & Volcaniclastic turbidite & - & - & $x$ & - & $\mathrm{xx}$ & $\mathrm{xxx}$ & $\mathrm{xx}$ & \\
\hline $47 R-2,140-150$ & 422 & Volcaniclastic siltstone & - & - & $\stackrel{-}{-}$ & - & 0 & $x x x$ & $x$ & Celadonite $\mathrm{x}$ \\
\hline $50 \mathrm{R}-2,140-150$ & 450 & Volcaniclastic silty claystone & - & - & $\mathrm{xx}$ & - & $\mathrm{x}$ & $\mathrm{xxx}$ & $\mathrm{x}$ & Celadonite o \\
\hline $53 \mathrm{R}-1,120-130$ & 471 & Calcareous volcaniclastic claystone & $\mathrm{xx}$ & - & $x$ & - & $\mathrm{xx}$ & $x$ & 0 & \\
\hline $56 \mathrm{R}-2,140-150$ & 500 & Volcaniclastic turbidite & - & - & - & - & o & $x x$ & - & Sanidine $\mathrm{xxx}$ \\
\hline
\end{tabular}

Note: Qualitative estimates of the abundance based on peak height: $x x x x x>90 \%, x=5 \%, 0=$ detected, $-=$ not detected. aDepth rounded to the nearest meter. 
Table 3. Major element composition of solid sediment (squeeze cake) in interstitial water samples.

\begin{tabular}{|c|c|c|c|c|c|c|c|c|c|c|c|c|c|}
\hline $\begin{array}{l}\text { Core, section, } \\
\text { interval }(\mathrm{cm})\end{array}$ & $\begin{array}{l}\text { Depth }^{2} \\
\text { (mbsf) }\end{array}$ & $\begin{array}{l}\mathrm{SiO}_{2} \\
\text { (wt\%) }\end{array}$ & $\begin{array}{l}\mathrm{Al}_{2} \mathrm{O}_{3} \\
\text { (wt\%) }\end{array}$ & $\begin{array}{l}\mathrm{Fe}_{2} \mathrm{O}_{3}{ }^{\mathrm{t}} \\
(\mathrm{w} \%)\end{array}$ & $\begin{array}{l}\mathrm{MnO} \\
\text { (wt\%) }\end{array}$ & $\begin{array}{l}\mathrm{MgO} \\
\left(w t^{\prime}\right)\end{array}$ & $\begin{array}{c}\mathrm{CaO} \\
(\mathrm{wt} \%)\end{array}$ & $\begin{array}{l}\mathrm{Na}_{2} \mathrm{O} \\
(\mathrm{wt} \%)\end{array}$ & $\begin{array}{c}\mathrm{K}_{2} \mathrm{O} \\
\text { (wt\%) }\end{array}$ & $\begin{array}{l}\mathrm{TiO}_{2} \\
\text { (wt \%) }\end{array}$ & $\begin{array}{l}\mathrm{P}_{2} \mathrm{O}_{5} \\
(\mathrm{wt} \%)\end{array}$ & $\begin{array}{c}\text { Loss } \\
\text { on ignition }\end{array}$ & $\begin{array}{l}\text { Total } \\
\text { (wt\%) }\end{array}$ \\
\hline \multicolumn{14}{|l|}{$129-800 \mathrm{~A}-$} \\
\hline $4 \mathrm{R}-2,25-30$ & 22 & 49.10 & 14.78 & 6.41 & 2.29 & 3.11 & 4.45 & 1.92 & 3.94 & 0.59 & 2.41 & 11.14 & 100.14 \\
\hline $26 \mathrm{R}-2,140-148$ & 232 & 64.72 & 6.35 & 6.07 & 0.08 & 3.17 & 4.67 & 1.82 & 2.49 & 1.12 & 0.20 & 9.07 & 99.76 \\
\hline $27 \mathrm{R}-1,140-150$ & 239 & 53.50 & 9.58 & 10.03 & 0.15 & 6.20 & 6.58 & 2.29 & 0.88 & 1.79 & 0.27 & 8.11 & 99.38 \\
\hline $33 R-6,60-70$ & 296 & 45.57 & 10.63 & 12.23 & 0.15 & 8.21 & 5.01 & 1.50 & 4.83 & 1.51 & 0.39 & 10.39 & 100.42 \\
\hline $37 R-2,0-10$ & 327 & 46.56 & 9.26 & 10.61 & 0.17 & 14.66 & 1.61 & 2.52 & 2.18 & 1.52 & 0.27 & 10.13 & 99.49 \\
\hline $41 \mathrm{R}-2,0-10$ & 364 & 53.96 & 9.13 & 9.23 & 0.11 & 11.36 & 2.09 & 1.87 & 1.58 & 1.43 & 0.24 & 8.63 & 99.63 \\
\hline $49 \mathrm{R}-2,140-150$ & 434 & 43.04 & 8.78 & 13.01 & 0,11 & 12.11 & 5.83 & 1.86 & 0.94 & 1.47 & 0.24 & 12.33 & 99.72 \\
\hline $54 \mathrm{R}-2,0-12$ & 473 & 81.18 & 5.09 & 3.92 & 0.40 & 1.45 & 0.56 & 0.77 & 1.41 & 0.32 & 0.20 & 5.01 & 100.31 \\
\hline \multicolumn{14}{|l|}{ 129-801A- } \\
\hline $3 R-2,145-150$ & 15 & 49.56 & 16.82 & 7.34 & 2.15 & 3.27 & 1.85 & 2.09 & 4.15 & 0.61 & 1.04 & 11.43 & 100.31 \\
\hline $5 R-3,145-150$ & 36 & 54.46 & 15.13 & 6.0 .4 & 0.96 & 2.97 & 1.75 & 2.09 & 4.27 & 0.55 & 0.98 & 10.51 & 99.71 \\
\hline $19 \mathrm{R}-1,65-73$ & 167 & 63.62 & 6.76 & 6.40 & 0.08 & 3.67 & 4.76 & 1.97 & 2.16 & 1.36 & 0.26 & 9.24 & 100.28 \\
\hline \multicolumn{14}{|l|}{$129-801 \mathrm{~B}-$} \\
\hline $5 R-2,0-10$ & 225 & 48.22 & 9.03 & 9.78 & 0.14 & 8.16 & 5.20 & 1.81 & 4.83 & 2.09 & 0.38 & 10.12 & 99.76 \\
\hline $8 \mathrm{R}-3,115-125$ & 257 & 56.34 & 8.21 & 9.42 & 0.17 & 6.20 & 3.37 & 2.02 & 2.66 & 1.70 & 0.28 & 9.07 & 99.44 \\
\hline $33 \mathrm{R}-1,143-150$ & 436 & 73.10 & 7.28 & 7.19 & 0.02 & 1.67 & 0.28 & 0.93 & 2.29 & 0.51 & 0.15 & 6.15 & 99.57 \\
\hline $35 \mathrm{R}-2,0-10$ & 446 & 65.00 & 8.41 & 11.21 & 0.08 & 2.04 & 0.48 & 1.02 & 2.72 & 0.60 & 0.27 & 7.74 & 99.57 \\
\hline \multicolumn{14}{|l|}{$129-802 \mathrm{~A}-$} \\
\hline $4 \mathrm{R}-1,140-150$ & 26 & 40.23 & 9.80 & 10.35 & 0.07 & 8.76 & 7.76 & 3.29 & 2.00 & 2.75 & 0.35 & 14.31 & 99.67 \\
\hline $6 \mathrm{R}-2,0-10$ & 44 & 43.65 & 10.50 & 11.98 & 0.15 & 10.73 & 3.20 & 4.91 & 0.86 & 2.77 & 0.36 & 9.33 & 98.44 \\
\hline $10 \mathrm{R}-2,140-150$ & 83 & 41.92 & 11.03 & 12.55 & 0.17 & 8.36 & 5.41 & 4.70 & 0.29 & 3.08 & 0.41 & 11.57 & 99.49 \\
\hline $13 \mathrm{R}-1,53-58$ & 109 & 48.87 & 11.50 & 7.69 & 1.58 & 3.02 & 4.19 & 2.88 & 1.58 & 0.65 & 0.75 & 16.87 & 99.58 \\
\hline $19 \mathrm{R}-2,107-117$ & 162 & 43.67 & 10.16 & 11.58 & 0.17 & 9.73 & 7.13 & 3.72 & 1.04 & 2.47 & 0.32 & 9.74 & 99.73 \\
\hline $21 \mathrm{R}-1,103-110$ & 179 & 43.32 & 10.71 & 11.13 & 0.15 & 8.38 & 6.44 & 3.97 & 1.51 & 2.62 & 0.36 & 10.28 & 98.87 \\
\hline $26 \mathrm{R}-1,0-10$ & 225 & 37.59 & 9.89 & 8.60 & 0.20 & 4.47 & 14.98 & 2.61 & 1.72 & 1.53 & 0.27 & 17.70 & 99.56 \\
\hline $29 \mathrm{R}-3,29-34$ & 258 & 52.71 & 10.96 & 8.33 & 2.02 & 2.88 & 3.55 & 2.70 & 1.63 & 0.51 & 0.83 & 13.63 & 99.75 \\
\hline $32 \mathrm{R}-2,140-150$ & 286 & 27.75 & 3.41 & 1.62 & 0.45 & 0.86 & 33.42 & 0.72 & 0.41 & 0.16 & 0.56 & 29.91 & 99.27 \\
\hline $36 \mathrm{R}-1,80-88$ & 322 & 6.61 & 1.31 & 0.58 & 0.14 & 0.44 & 49.04 & 0.08 & 0.03 & 0.08 & 0.40 & 40.18 & 98.89 \\
\hline $40 R-2,140-150$ & 361 & 49.53 & 11.60 & 12.96 & 0.12 & 5.19 & 6.22 & 2.45 & 1.64 & 3.18 & 0.44 & 6.37 & 99.70 \\
\hline $43 \mathrm{R}-1,140-150$ & 384 & 43.45 & 8.21 & 8.80 & 0.16 & 6.12 & 11.89 & 1.95 & 1.63 & 2.42 & 0.30 & 14.40 & 99.33 \\
\hline $47 \mathrm{R}-2,140-150$ & 422 & 49.25 & 9.35 & 11.10 & 0.14 & 11.21 & 4.39 & 2.17 & 0.55 & 2.50 & 0.32 & 8.76 & 99.74 \\
\hline $50 \mathrm{R}-2,140-150$ & 450 & 51.34 & 9.48 & 10.55 & 0.19 & 10.19 & 2.75 & & 1.04 & 2.50 & 0.27 & 9.62 & 100.09 \\
\hline $53 \mathrm{R}-1,120-130$ & 471 & 48.15 & 7.94 & 5.77 & 0.07 & 2.22 & 15.30 & 1.56 & 1.20 & 0.97 & 0.25 & 16.73 & 100.16 \\
\hline $56 \mathrm{R}-2,140-150$ & 500 & 55.14 & 11.55 & 9.07 & 0.04 & 4.44 & 1.28 & 1.29 & 7.00 & 0.97 & 0.12 & 8.95 & 99.85 \\
\hline
\end{tabular}

Note: $\mathrm{Fe}_{2} \mathrm{O}_{3}{ }^{1}$ as total iron.

${ }^{2}$ Depth rounded to the nearest meter. 
Table 4. Carbonate content and trace element composition of solid sediment in interstitial water samples.

\begin{tabular}{|c|c|c|c|c|c|c|c|c|c|c|c|c|c|c|}
\hline $\begin{array}{l}\text { Core, section, } \\
\text { interval }(\mathrm{cm})\end{array}$ & $\begin{array}{l}\mathrm{CaCO}_{3}{ }^{\mathrm{a}} \\
(\mathrm{wt} \%)\end{array}$ & B & $\mathrm{Ba}$ & C & $\mathrm{Cr}$ & $\mathrm{Cu}$ & $\mathrm{Ni}$ & $\mathrm{Rb}$ & $\mathrm{Sr}$ & $\mathrm{Tb}$ & $\mathrm{v}$ & $\mathrm{Y}$ & $\mathrm{Zn}$ & $\mathrm{Zr}$ \\
\hline \multicolumn{15}{|l|}{$129-800 \mathrm{~A}-$} \\
\hline $4 \mathrm{R}-2,25-30$ & 0.6 & 141 & 400 & 256 & 51 & 385 & 581 & 86 & 269 & 13 & 127 & 503 & 201 & 154 \\
\hline $26 \mathrm{R}-2,140-148$ & 5.3 & 29 & 60 & 15 & 122 & 79 & 46 & 36 & 493 & $<5$ & 101 & 10 & 50 & 78 \\
\hline $27 \mathrm{R}-1,140-150$ & 2 & 31 & 81 & 37 & 482 & 113 & 184 & 18 & 362 & $<5$ & 168 & 17 & 83 & 127 \\
\hline $33 R-6,60-70$ & 8.2 & 55 & 61 & 32 & 374 & 82 & 167 & 48 & 105 & $<5$ & 165 & 22 & 74 & 117 \\
\hline $37 \mathrm{R}-2,0-10$ & 0.7 & 50 & 21 & 32 & 586 & 97 & 276 & 46 & 107 & $<5$ & 98 & 12 & 86 & 111 \\
\hline $4 \mathrm{IR}-2,0-10$ & 1.2 & 38 & 18 & 41 & 623 & 111 & 265 & 31 & 134 & $<5$ & 169 & 12 & 77 & 106 \\
\hline $49 \mathrm{R}-2,140-150$ & 0.2 & 30 & $<5$ & 43 & 791 & 25 & 276 & 17 & 124 & $<5$ & 268 & 15 & 70 & 100 \\
\hline $54 \mathrm{R}-2,0-12$ & 0.2 & 39 & 745 & 11 & 22 & 70 & 39 & 44 & 69 & $<5$ & 42 & 10 & 82 & 54 \\
\hline \multicolumn{15}{|l|}{$129-801 \mathrm{~A}-$} \\
\hline $3 R-2,145-150$ & & 147 & 392 & 209 & 63 & 285 & 481 & 121 & 168 & 15 & 119 & 243 & 173 & 151 \\
\hline $5 R-3,145-150$ & & 152 & 310 & 101 & 53 & 261 & 261 & 101 & 169 & 6 & 100 & 154 & 153 & 130 \\
\hline $19 \mathrm{R}-1,65-73$ & & 29 & 211 & 10 & 188 & 67 & 49 & 32 & 310 & $<5$ & 110 & 13 & 67 & 114 \\
\hline \multicolumn{15}{|l|}{ 129-80IB- } \\
\hline $5 R-2,0-10$ & 4.3 & 39 & 50 & 26 & 465 & 88 & 167 & 67 & 189 & 6 & 174 & 17 & 75 & 173 \\
\hline $8 R-3,115-125$ & 4 & 41 & 112 & 37 & 233 & 54 & 124 & 39 & 199 & $<5$ & 136 & 12 & 71 & 126 \\
\hline $33 \mathrm{R}-1,143-150$ & & 51 & 214 & 523 & 60 & 77 & 71 & 73 & 79 & $<5$ & 89 & 6 & 75 & 93 \\
\hline $35 \mathrm{R}-2,0-10$ & & 75 & 178 & 627 & 50 & 83 & 101 & 85 & 84 & $<5$ & 138 & 16 & 101 & 108 \\
\hline \multicolumn{15}{|l|}{ 129-802A- } \\
\hline $4 \mathrm{R}-1,140-150$ & 10 & 51 & 84 & 64 & 597 & 110 & 66.4 & 29 & 97 & $<5$ & 258 & 26 & 82 & 182 \\
\hline $6 \mathrm{R}-2,0-10$ & 0.7 & 47 & 61 & 51 & 648 & 123 & 298 & 12 & 123 & $<5$ & 281 & 27 & 98 & 183 \\
\hline $10 \mathrm{R}-2,140-150$ & 1.8 & 26 & 54 & 66 & 550 & 134 & 252 & 7 & 308 & $<5$ & 295 & 29 & 101 & 203 \\
\hline $13 R-1,53-58$ & 0.5 & 56 & 229 & 167 & 45 & 322 & 259 & 29 & 1484 & 5 & 67 & 122 & 137 & 124 \\
\hline $19 \mathrm{R}-2,107-117$ & 3 & 22 & 114 & 48 & 694 & 103 & 328 & 14 & 127 & $<5$ & 258 & 24 & 93 & 161 \\
\hline $21 \mathrm{R}-1,103-110$ & 2.7 & 28 & 94 & 60 & 487 & 112 & 280 & 19 & 158 & $<5$ & 216 & 23 & 93 & 169 \\
\hline $26 \mathrm{R}-1,0-10$ & 21.8 & 41 & 261 & 58 & 260 & 69 & 156 & 27 & 414 & $<5$ & 204 & 24 & 76 & 101 \\
\hline $29 \mathrm{R}-3,29-34$ & 0.4 & 112 & 886 & 75 & 31 & 332 & 81 & 30 & 780 & 5 & 126 & 138 & 157 & 113 \\
\hline $32 \mathrm{R}-2,140-150$ & 53.5 & 37 & 454 & 21 & 15 & 88 & 67 & 16 & 676 & 13 & 19 & 76 & 56 & 31 \\
\hline $36 \mathrm{R}-1,80-88$ & 85.4 & 24 & 442 & 7 & 12 & 48 & 17 & 13 & 494 & 16 & 7 & 52 & 17 & 13 \\
\hline $40 \mathrm{R}-2,140-150$ & 0.5 & 41 & 108 & 27 & 313 & 140 & 119 & 28 & 391 & 6 & 274 & 29 & 141 & 204 \\
\hline $43 \mathrm{R}-1,140-150$ & 13 & 35 & 68 & 3 & 470 & 114 & 209 & 26 & 303 & $<5$ & 231 & 19 & 85 & 162 \\
\hline $47 \mathrm{R}-2,140-150$ & 2.2 & 25 & 47 & 33 & 526 & 134 & 223 & 9 & 236 & $<5$ & 257 & 19 & 96 & 166 \\
\hline $50 \mathrm{R}-2,140-150$ & 1.7 & 31 & 185 & 52 & 767 & 122 & 230 & 14 & 294 & $<5$ & 285 & 15 & 85 & 184 \\
\hline $53 \mathrm{R}-1,120-130$ & 23.2 & 41 & 118 & 28 & 110 & 53 & 96 & 24 & 346 & 5 & 91 & 23 & 79 & 109 \\
\hline $56 \mathrm{R}-2,140-150$ & 0.6 & 47 & $<5$ & 45 & 161 & 119 & 93 & 78 & 53 & $<5$ & 237 & 4 & 70 & 47 \\
\hline
\end{tabular}

Notes: All analyses are in parts per million (ppm) except for $\mathrm{CaCO}_{3}$, which is in weight percentage (wt\%).

aShipboard analyses (Lancelot, Larson, et al., 1990).

Table $5 .{ }^{87} \mathrm{Sr} /{ }^{86} \mathrm{Sr}$ in solid sediments for the leachable fraction (carbonates) and the silicate residue.

\begin{tabular}{lccrr}
\hline & \multicolumn{2}{c}{ Silicate residue } & \multicolumn{2}{c}{ Leachate } \\
$\begin{array}{l}\text { Core, section, } \\
\text { interval }(\mathrm{cm})\end{array}$ & ${ }^{87} \mathrm{Sr} /{ }^{86} \mathrm{Sr}$ & $\mathrm{Sr}(\mathrm{ppm})$ & $87 \mathrm{Sr} /{ }^{86} \mathrm{Sr}$ & $\mathrm{Sr}(\mathrm{ppm})$ \\
\hline $129-802 \mathrm{~A}-$ & & & & \\
& & & & \\
10R-2, $140-150$ & $0.703832 \pm 17$ & 49 & $0.704219 \pm 31$ & 658 \\
13R-1, 53-58 & $0.704380 \pm 37$ & 1093 & $0.704458 \pm 29$ & 2452 \\
36R-2, 80-88 & & & $0.707668 \pm 23$ & 457 \\
40R-2, 140-150 & $0.704487 \pm 14$ & 292 & $0.706747 \pm 23$ & 347 \\
43R-1, 140-150 & $0.705158 \pm 27$ & 217 & $0.707050 \pm 21$ & 202 \\
47R-2, 140-150 & $0.704541 \pm 27$ & 121 & $0.706931 \pm 17$ & 267 \\
53R-1, 120-130 & $0.707043 \pm 21$ & 227 & $0.707336 \pm 34$ & 403 \\
\hline
\end{tabular}




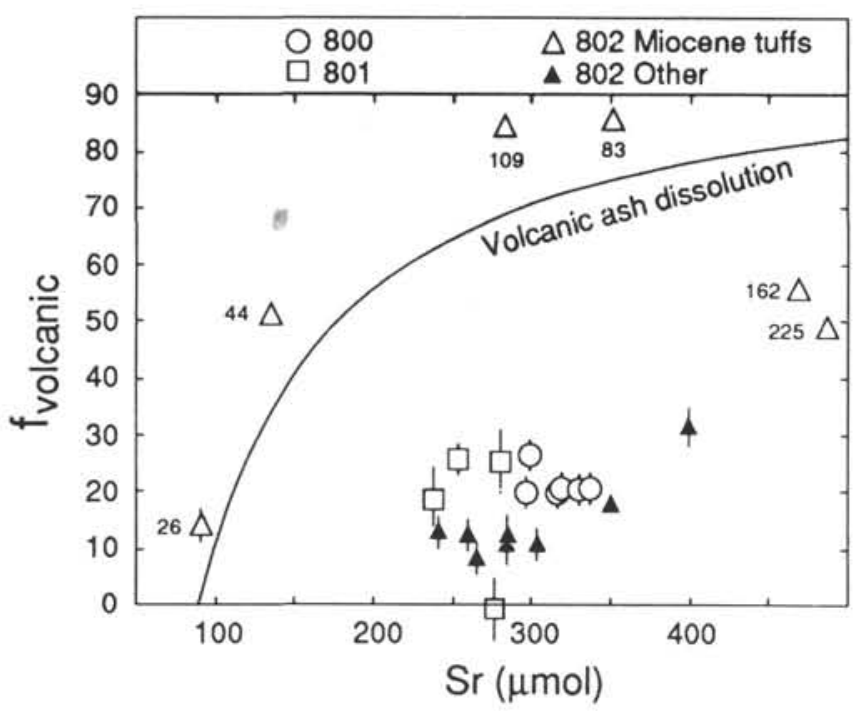

Figure 6. Sr content of interstitial water samples of the three sites vs. the fraction of volcanic Sr calculated from the Sr isotope ratio of pore water, contemporaneous seawater, and volcanic matter (see text). The vertical error bar corresponds to the uncertainty of the ${ }^{87} \mathrm{Sr} /{ }^{86} \mathrm{Sr}$ ratio of contemporaneous seawater. The curve corresponds to a dissolution of basalt in interstitial water. ${ }^{87} \mathrm{Sr} /{ }^{86} \mathrm{Sr}$ of volcanic matter has been taken at 0.7035 , as it corresponds to average ${ }^{87} \mathrm{Sr}{ }^{86} \mathrm{Sr}$ ratio of Cretaceous volcanism in the area (e.g., Smith et al., 1989; Castilloet al., this volume). Addition of biogenic $\mathrm{Sr}$ is necessary to explain the samples in which $\mathrm{Sr}$ is higher than expected for a given value of $f_{\text {volcanic }}$. The numbers with the Miocene tuff symbols (802) indicate the sub-bottom depth.

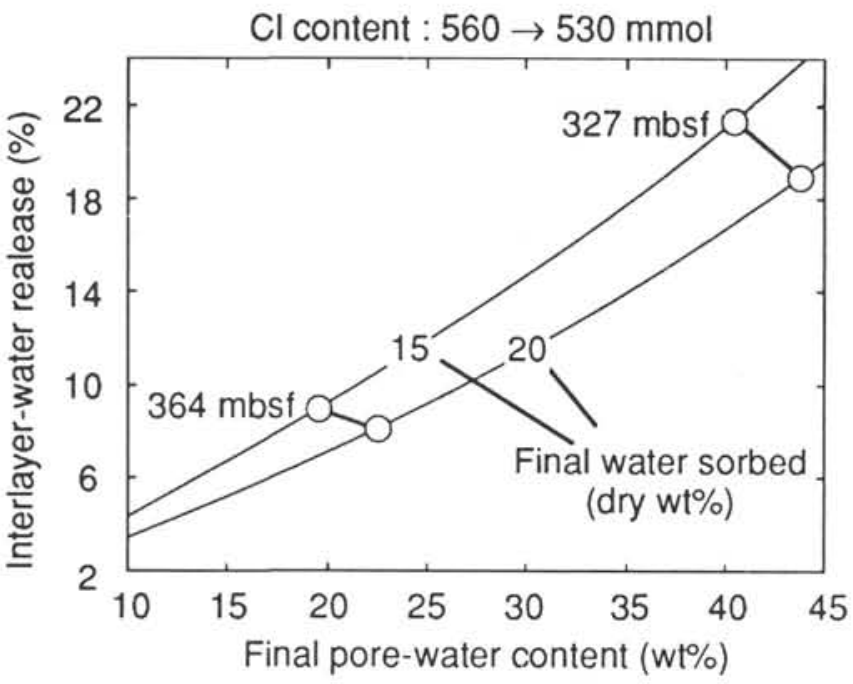

Figure 7. Estimate of interlayer-water dewatering for a $5.4 \%$ freshening of the pore water $(560 \rightarrow 530 \mathrm{mmol} \mathrm{Cl})$ as a function of the final pore-water content of the sediment and the final interlayer water content of the smectite in a $90 \%$ smectite sediment. Interlayer-water dewatering corresponds to $\left(1-I_{\text {final }} / I_{\text {initial }}\right) \cdot 100$. Points at 327 and 364 mbsf correspond to Samples $129-800 \mathrm{~A}-37 \mathrm{R}-2,0-10 \mathrm{~cm}$, and $129-800 \mathrm{~A}-4 \mathrm{IR}-2,0-10 \mathrm{~cm}$, respectively, for which estimates of the pore-water content have been made from bulk water content measurements (France-Lanord and Sheppard, this volume).

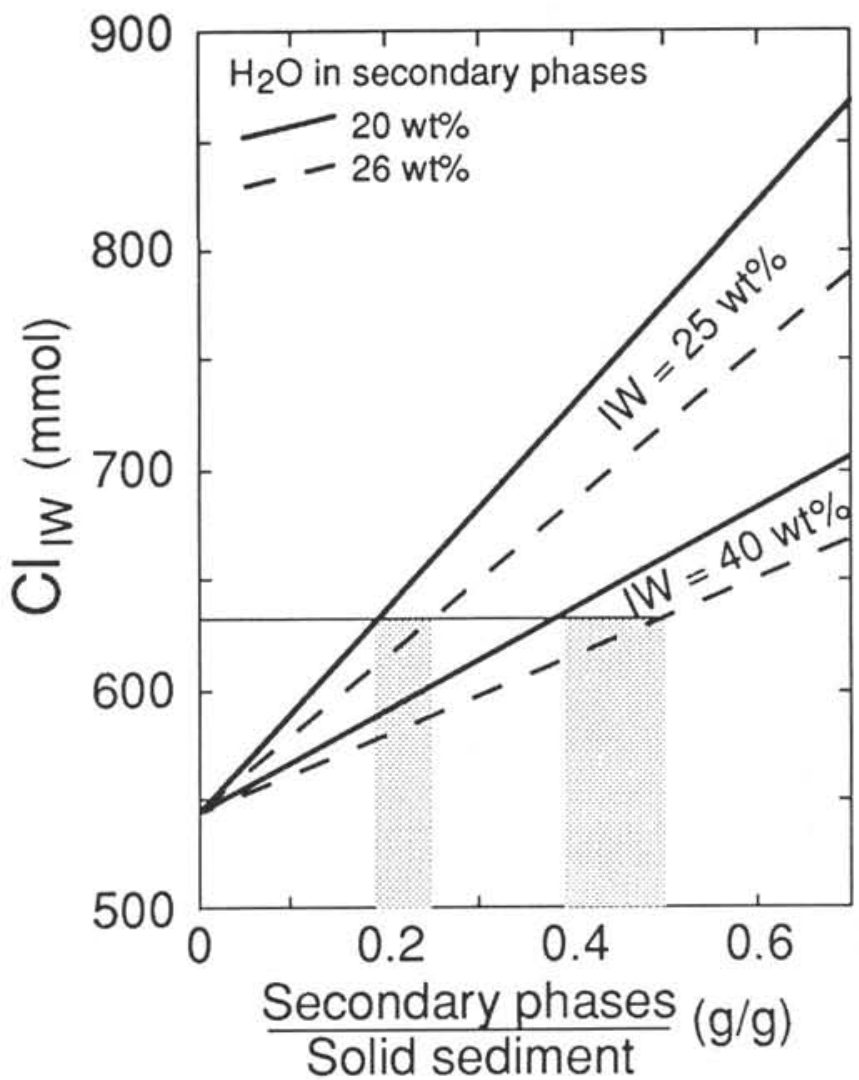

Figure 8 . Chlorine increase by water uptake during alteration of a volcaniclastic sediment in a closed system. The initial fluid is seawater with $545 \mathrm{mmol} \mathrm{Cl}$. The two line groups correspond to 25 and $40 \mathrm{wt} \%$ final water content in the sediment. Secondary phases contain 20 and $26 \mathrm{wt} \%$ of total water, which correspond to 0.25 and $0.35 \mathrm{~g} / \mathrm{g}$ of water sorbed. The fraction of altered mineral is expressed as dry weight. 